Louisiana State University

LSU Digital Commons

Faculty Publications

Department of Oceanography \& Coastal

Sciences

6-16-2009

\title{
Nutrient Limitation On Phytoplankton Growth In The Upper Barataria Basin, Louisiana: Microcosm Bioassays
}

\author{
Ling Ren \\ Iren2@gmu.edu \\ Nancy N. Rabalais \\ nrabalais@lumcon.edu \\ R. Eugene Turner \\ euturne@lsu.edu \\ Wendy Morrison \\ Warren Mendenhall
}

Follow this and additional works at: https://digitalcommons.Isu.edu/oceanography_coastal_pubs

Digitadrt of the Oceanography Commons

Commons

Network

Recommended Citation

Reñ, L., Rabalais, N. N., Turner, R., Morrison, W., \& Mendenhall, W. (2009). Nutrient Limitation On

Phytoplankton Growth In The Upper Barataria Basin, Louisiana: Microcosm Bioassays. https://doi.org/

10.1007/s12237-009-9174-8

This Article is brought to you for free and open access by the Department of Oceanography \& Coastal Sciences at LSU Digital Commons. It has been accepted for inclusion in Faculty Publications by an authorized administrator of LSU Digital Commons. For more information, please contact ir@lsu.edu. 


\title{
Nutrient Limitation on Phytoplankton Growth in the Upper Barataria Basin, Louisiana: Microcosm Bioassays
}

\author{
Ling Ren • Nancy N. Rabalais • R. Eugene Turner • \\ Wendy Morrison • Warren Mendenhall
}

Received: 3 April 2008 /Revised: 7 April 2009 /Accepted: 20 May 2009/Published online: 16 June 2009

(C) Coastal and Estuarine Research Federation 2009

\begin{abstract}
The Davis Pond Diversion (DPD) was constructed to divert Mississippi River (MR) water into the Barataria Basin to reduce the salinity in support of wetland restoration on the Louisiana coast. To assess the phytoplankton nutrient limitation in adjacent water systems and potential impacts of DPD, 12 seasonal nutrient-phytoplankton bioassay experiments were conducted from October 2003 to July 2004 using the natural phytoplankton assemblages from freshwater and brackish-water lakes, Cataouatche and Salvador, LA (USA), which receive Mississippi River water from the DPD, and from a nearby freshwater lake, Lac des Allemands, that does not. Dissolved inorganic nitrogen $(\mathrm{N})$, phosphorus $(\mathrm{P})$, and silicate $(\mathrm{Si})$ were added with different combinations at Redfield ratios in 101 microcosms. Nitrogen was found to be the sole or primary limiting nutrient in all 12 experiments. $\mathrm{N}$ and $\mathrm{P}$ colimitations were found in seven of 12 experiments, but $\mathrm{N}$ was always the stronger limiting factor. $\mathrm{P}$ limitation was never observed to be the sole limiting nutrient. The results showed that a low concentration of $\mathrm{P}$ and a relatively high concentration of $\mathrm{N}$ do not necessarily indicate only $\mathrm{P}$
\end{abstract}

L. Ren $\cdot$ N. N. Rabalais $\cdot$ W. Morrison $\cdot$ W. Mendenhall

Louisiana Universities Marine Consortium,

8124, Highway 56,

Chauvin, LA 70344, USA

R. E. Turner

Dept of Oceanography and Coastal Sciences,

Louisiana State University,

Baton Rouge, LA 70803, USA

L. Ren $(\square)$

Patrick Center for Environmental Research,

Academy of Natural Sciences,

1900 Ben Franklin Parkway,

Philadelphia, PA 19103, USA

e-mail: ren@ansp.org limitation in these lakes. Lake Cataouatche and Lake Salvador were dominated by centric diatoms, and Anabaena spp. were detected at high levels, particularly in summer. Lac des Allemands was generally dominated by $\mathrm{N}$-fixing Anabaena spp. and other cyanobacteria, and their biomass responded significantly to $\mathrm{N}$ addition but not to $\mathrm{P}$ addition, indicating that nitrogen fixation in Lac des Allemands may be inhibited by other factors such as iron. Our bioassay results demonstrate that whether a water body is $\mathrm{N}$ - or P-limited is the consequence of the nutrient status and not the salinity regime. The results suggest that the addition of nutrient-rich waters via diversions of Mississippi River water into these lakes might increase the frequency of algal blooms, including noxious and toxic freshwater cyanobacteria.

Keywords Nutrient limitation · Microcosm bioassays . Phytoplankton growth - Cyanobacteria .

Harmful algal blooms · Barataria estuary · Eutrophication . Mississippi River

\section{Introduction}

Nutrient loading, concentration, and ratios are strong selective forces shaping phytoplankton communities and may change for several reasons. The Davis Pond Diversion (DPD) brings Mississippi River water into the Barataria estuary of south Louisiana (USA) to lower salinity, to introduce sediments, and to fertilize wetlands with the hope that Louisiana's significantly high wetland-to-open water habitat conversion rates $\left(26 \mathrm{~km}^{2}\right.$ year ${ }^{-1}$ from 1990 to 2001; Morton et al. 2005) will be reduced, if not reversed (Boesch et al. 1994). There are questions about how much the increased nutrient loads from diverted Mississippi River 
and the reduction in salinity will expose the upper Barataria estuary to more frequent and longer freshwater phytoplankton blooms, including noxious and toxic forms. The diversion size (maximum $280 \mathrm{~m}^{3} \mathrm{~s}^{-1}$ ), the ability to control its timing, and the geomorphologically restricted receiving basin are a large and "applied" natural experiment about coastal eutrophication. Understanding the potential effects of introduction of fresher nutrient-rich waters into brackish systems is a necessary step in better predictions of how diversions of Mississippi River water will affect adjacent aquatic ecosystems.

Understanding nutrient limitation is an essential component of an assessment of phytoplankton growth under increasing nutrient loading. Three general strategies or approaches used to examine the nutrient limitations of phytoplankton growth are to: (1) establish nutrient uptake kinetics (Riegman et al. 1990; Fisher et al. 1995; Nelson and Dortch 1996), (2) determine nutrient criteria, and (3) conduct experimental bioassays. A widely used method is to compare the in situ nutrient concentrations or ratios with predetermined criteria defining the threshold nutrient concentrations for phytoplankton uptake, e.g., Redfield (1958) ratios. Applying nutrient criteria to water bodies has obvious cost benefits because the method does not require laboratory or field experiments when adequate nutrient data are accessible. Applying nutrient criteria to water bodies can be a good starting point to explore what nutrient(s) limit algal growth but cannot provide definitive conclusions about the actual limiting nutrients in the absence of other data because, for example, (a) nutrient regeneration rates vary among different communities, (b) phytoplankton growth may depend more on their intracellular nutrient quota than the external nutrient concentration and ratios, (c) total nitrogen (TN) and total phosphorus (TP) may be a better indicator of algal nutrient limitations than dissolved inorganic nitrogen (DIN) and phosphorus (Guildford and Hecky 2000; Dodds 2006). Furthermore, because phytoplankton elemental composition differs considerably among taxonomic groups and nutrient conditions, the criteria, particularly $\mathrm{N}$ to $\mathrm{P}$ (or $\mathrm{TN}$ to $\mathrm{TP}$ ) ratios used to determine $\mathrm{N}$ or $\mathrm{P}$ limitation, vary in different studies (Dortch and Whitledge 1992; Falkwoski 1997; Tyrrell 1999; Guildford and Hecky 2000). These variations introduce substantial difficulties when applying nutrient criteria to specific aquatic ecosystems.

Bioassays are, by far, the dominant experimental approach used to determine nutrient limitation (Maestrini et al. 1986; Peeters and Peperzak 1990; Levine and Whalen 2001; James et al. 2003; Fujiki et al. 2004; Dzialowski et al. 2005; Wang et al. 2005; Gobler et al. 2006; Klug 2006; Sylvan et al. 2006). The results of bioassay experiments have been used to define the critical TN to TP ratios on $\mathrm{N}$ or $\mathrm{P}$ limitation for regional water management recommen- dations (Dzialowski et al. 2005; Wang et al. 2005). Although some bioassays do not represent all aspects of the natural systems because of the experimental artifacts inherent to the experiments (Hecky and Kilham 1988), bioassays are helpful to ascertain which nutrient is potentially the first to limit phytoplankton growth and to rank the other nutrients in the order of their increasing likelihood of becoming limiting.

We used bioassays to determine nutrient limitation of phytoplankton growth in two lakes receiving water from the DPD (Lake Cataouatche and Lake Salvador) and a nearby lake that does not receive the DPD water (Lac des Allemands). We tested the hypothesis that the most frequently limiting nutrient would be phosphorus in a freshwater system and that there would be multiple nutrient limitations in brackish systems, with a propensity for phosphorus limitation. Four replicated bioassays in each lake were conducted seasonally from October 2003 to July 2004, covering periods of low and high discharges of DPD. Data on phytoplankton biomass, species composition, and nutrient concentrations were analyzed to characterize the biological and chemical status of each lake.

\section{Study Area}

The Barataria Basin is in southeast Louisiana and is bordered on the east by the west bank of the Mississippi River and on the west by Bayou Lafourche, which is a former tributary of the Mississippi River (Fig. 1). There are no natural river sources into the upper Barataria Basin. Precipitation is the major natural hydrologic input influencing nutrient loading and linking the upper, middle, and lower basins of the estuary. Nutrient loading to the upper basin is from agricultural and urban runoff from adjacent uplands. The DPD diverts Mississippi River into Lake Cataouatche through a holding area, then downstream to Lake Salvador and to the lower part of Barataria Basin. Lac des Allemands does not directly receive Mississippi River water from the DPD. It is, however, connected to Lake Salvador by Bayou des Allemands and receives runoff from surrounding areas. The DPD was constructed between 1997 and 2002 and began operations in July 2002. It had a daily discharge of less than 10 to $50 \mathrm{~m}^{3} \mathrm{~s}^{-1}$ in five isolated operation events until November 2003. The DPD was operated at its highest discharge (up to $280 \mathrm{~m}^{3} \mathrm{~s}^{-1}$ ) for 3 days in early December 2003 and dropped to $<100 \mathrm{~m}^{3} \mathrm{~s}^{-1}$ in the following 2 weeks (Swenson et al. 2006). The DPD discharged at an average rate of 30 to $40 \mathrm{~m}^{3} \mathrm{~s}^{-1}$ in 2004 (Fig. 2).

Data on the salinity, nutrients, and chlorophyll $a$ monitoring for 1998 to 2002 are summarized in Table 1 to show the ecological state of the three lakes before the DPD operation. These data are based on a monthly water 


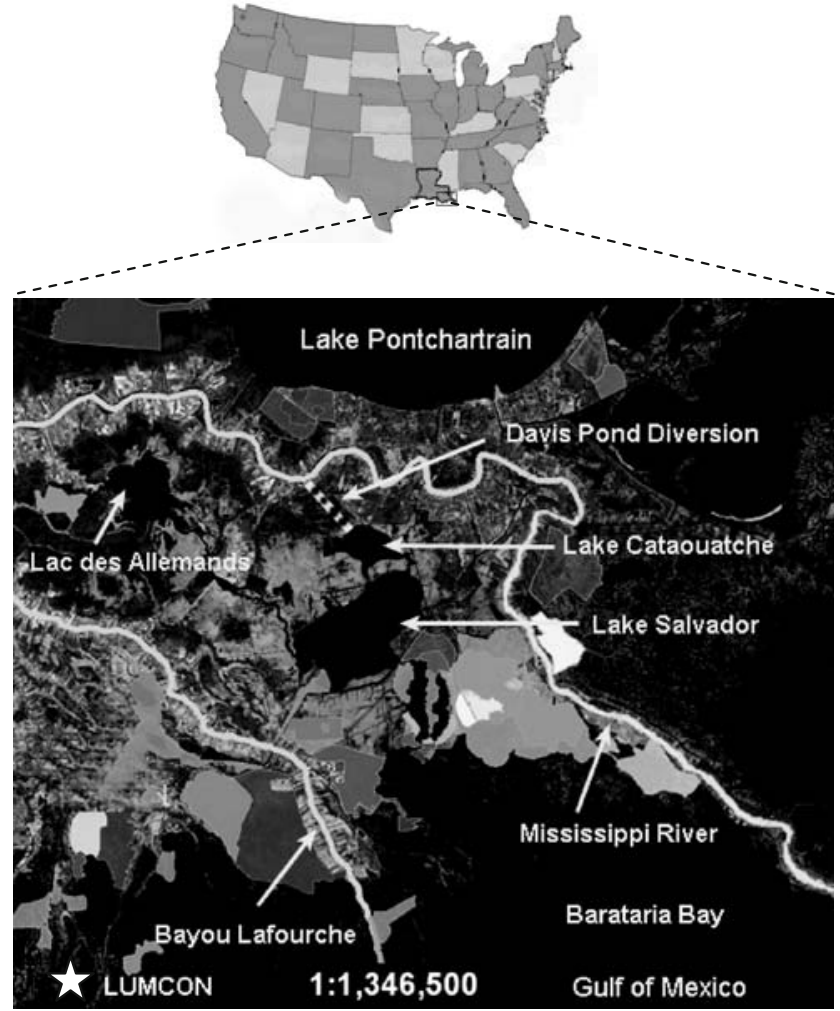

Fig. 1 Map of the study area, three lakes of concern, and location of the Davis Pond Diversion

quality monitoring of the Barataria Basin, consisting of 37 stations along a north-to-south transect going from the upper estuary ( $0.1 \mathrm{psu})$ to the Gulf of Mexico coastal waters (20 psu). There are eight additional stations in lakes Cataouatche and Salvador that were sampled biweekly since 1998 (R. E. Turner, unpublished data). A YSI 6600 EDS oxygen meter was deployed in each lake (N. N. Rabalais, unpublished data). Lake Cataouatche and Lake
Salvador are oligohaline systems with salinity ranges between 0.3 and $7.6 \mathrm{psu}$ and are generally controlled by runoff and precipitation. Lake Salvador is affected more by tidal action with a wider salinity range than Lake Cataouatche. Lac des Allemands is a freshwater system (salinity $<0.5 \mathrm{psu}$ ). The concentration of dissolved inorganic nitrogen ( $\mathrm{DIN}=\mathrm{NH}_{4}{ }^{+}+\mathrm{NO}_{2}{ }^{-}+\mathrm{NO}_{3}{ }^{-}$) in the three lakes was often below the threshold of phytoplankton uptake $(<1.0 \mu \mathrm{M})$, particularly in Lake Cataouatche and Lac des Allemands. The concentration of DIN in Lac des Allemands was lower than that in Lake Cataouatche and Lake Salvador. Lac des Allemands contained the highest concentration of phosphorus (soluble reactive phosphorus (SRP)) among the three lakes. As a result, the molar ratio of DIN to SRP is the lowest in Lac des Allemands (0.6 to 5.6). The DIN to SRP molar ratios in Lake Cataouatche and Lake Salvador ranged from 2 to 3 to as high as 54 to 165 . The concentration of silicate ( $\mathrm{Si}$ ) was generally high in all lakes and the ratio of DIN to Si was, therefore, low. The average concentration of chlorophyll $a$ was the highest in Lac des Allemands (23 to $105 \mu \mathrm{g} \mathrm{l^{-1 }}$ ), despite its low DIN concentration and DIN to SRP ratio. Lake Salvador contained the lowest concentration of chlorophyll $a$ (6 to $14 \mu \mathrm{g}^{-1}$ ). According to the definition of lake trophic state by Carlson (1977), Lake Salvador is slightly eutrophic. Lake Cataouatche is moderately eutrophic (chlorophyll $a 9$ to $30 \mu \mathrm{g}^{-1}$ ), and Lac des Allemands is hypereutrophic.

\section{Methods and Materials}

\section{Experimental Setup}

Four sets of experiments were conducted from October 2003 (Oct03), January 2004 (Jan04), April 2004 (Apr04),
Fig. 2 Daily discharge of Davis Pond Diversion from July 2002 to December 2004. Data source: US Geological Survey, Louisiana Department of Natural Resources. Plotted by E. M. Swenson, Coastal Ecology Institute, Louisiana State University. Bioassay periods indicated by black bars on $X$-axis

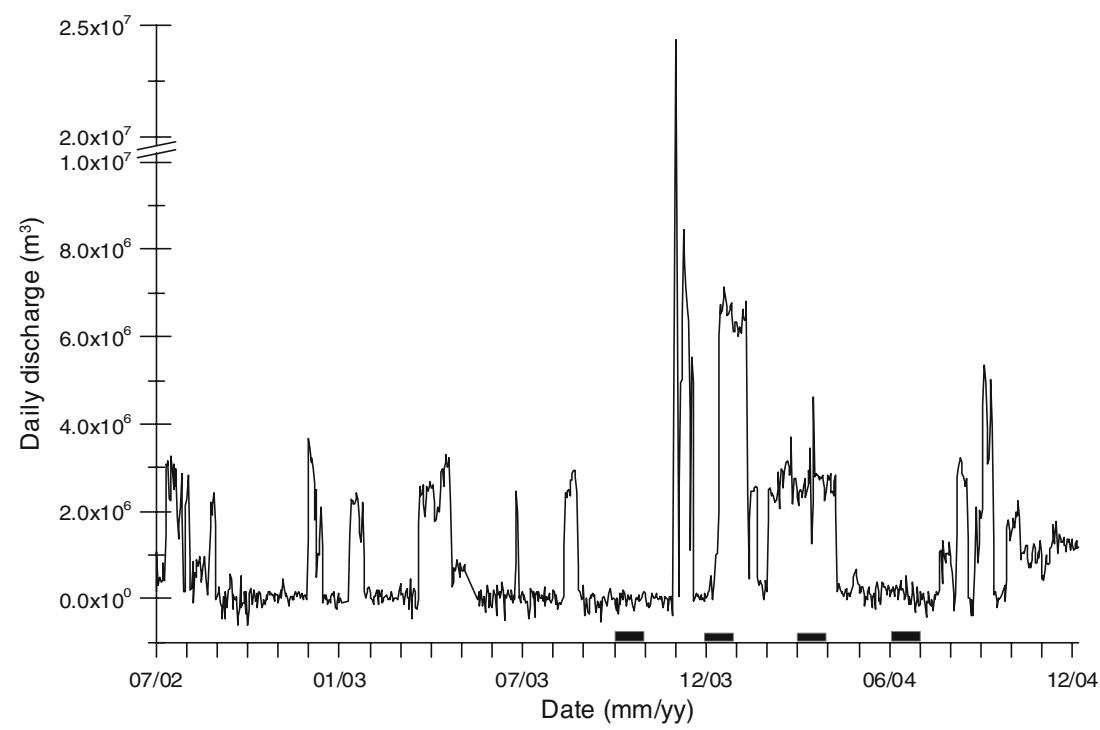


Table 1 Characterization of the three lakes sampled monthly from 1998 to 2002

${ }^{\text {a }}$ Follows classification of Carlsson (1977)

\begin{tabular}{|c|c|c|c|c|}
\hline & & Lake Cataouatche & Lake Salvador & Lac des Allemands \\
\hline \multicolumn{2}{|c|}{ Depth (m) } & Avg. $\sim 2$ & Avg. $\sim 1.7$ & $2-3$ \\
\hline \multicolumn{2}{|c|}{ Salinity (psu) } & $0.5-5.3$ & $0.3-7.6$ & $0.0-0.4$ \\
\hline \multirow[t]{3}{*}{ Nutrients } & $\mathrm{NO}_{3}^{-}(\mu \mathrm{M})$ & $0.3-27$ & $1.3-28$ & $0.3-2.7$ \\
\hline & $\operatorname{SRP}(\mu \mathrm{M})$ & $0.2-0.8$ & $0.5-1.7$ & $0.5-7.0$ \\
\hline & $\mathrm{Si}(\mu \mathrm{M})$ & $42-99$ & $40-104$ & 28-137 \\
\hline \multicolumn{2}{|c|}{ DIN: SRP } & $3.6-165$ & $2.7-54$ & $0.6-5.6$ \\
\hline \multicolumn{2}{|l|}{ DIN: Si } & $0.03-0.5$ & $0.05-0.4$ & $0.01-0.2$ \\
\hline \multicolumn{2}{|c|}{ Chlorophyll $a\left(\mu \mathrm{g} \mathrm{^{-1 } )}\right.$} & $9-30$ & $6-14$ & $23-105$ \\
\hline \multicolumn{2}{|c|}{ Trophic state $^{\mathrm{a}}$} & Moderately eutrophic & Slightly eutrophic & Hypereutrophic \\
\hline
\end{tabular}

and July 2004 (Jul04) for a total of 12 experimental manipulations. Lake water was collected from each lake at the station with the deployed oxygen meter. Water collection was in the late afternoon to minimize the effects of phytoplankton light inhibition around noon. The lake water was returned to the LUMCON Marine Center in Cocodrie, LA, USA, within $3 \mathrm{~h}$ and mixed in a 2001 polypropylene barrel. A 1-1 water sample was taken to represent conditions at the beginning of the experiment, and the remainder was immediately dispensed into 101 polycarbonate carboys (e.g., Sylvan et al. 2006). The carboys were placed in two incubators on a dock and ambient marina water was pumped continuously through the incubators to stabilize the temperature in the carboys. Whereas in situ phytoplankton in the lakes normally circulate within the water column by wind and other advective processes, the confines of the carboys would unavoidably hold the phytoplankton at near-surface ambient light conditions, which meant that the light exposure for the phytoplankton in our experiments was greater than what would be expected in the well-mixed 2- to 3-m-deep lake water. To compensate for light exposure, the incubators were wrapped with nylon screening to reduce the light intensity in the incubators by $50 \%$ (Levine and Whalen 2001). Except for the control microcosms, nutrients were added early the next morning in seven different combinations of duplicate treatments: $+\mathrm{N},+\mathrm{P},+\mathrm{Si}$, $+\mathrm{N}+\mathrm{P},+\mathrm{N}+\mathrm{Si},+\mathrm{P}+\mathrm{Si}$, and $+\mathrm{N}+\mathrm{P}+\mathrm{Si}$. The amounts of added nitrogen $(\mathrm{N})$ were estimated according to the following assumptions: (1) the concentration of $1 \mu \mathrm{g}^{-1}$ of chlorophyll $a$ equals approximately $1 \mu \mathrm{mol} 1^{-1}$ particulate nitrogen (Wilkerson et al. 2000; Ren 2002); (2) the phytoplankton biomass doubles over 1 day, and the demand of dissolved inorganic nitrogen (DIN) for phytoplankton growth approximately equals the increase of particulate $\mathrm{N}$; (3) enough of the nutrients must be added to allow the enclosed phytoplankton to grow for at least 2 days at a daily doubling rate. The DIN added (as $\mathrm{NaNO}_{3}$ ) was then calculated based on the initial concentration of chlorophyll $a$ in the lake water. The amount of added $\mathrm{P}$ (as $\left.\mathrm{NaH}_{2} \mathrm{PO}_{4}\right)$ and $\mathrm{Si}$ (as $\mathrm{Na}_{2} \mathrm{SiO}_{3}$ ) was proportional to the amount of added $\mathrm{NO}_{3}{ }^{-}$and the Redfield ratios ( $\mathrm{N}$ to $\mathrm{P}$ to $\mathrm{Si}=16: 1: 16$ ). A 1-1 water sample was taken from each carboy after nutrient additions at time $=0$. Subsequent sampling was at 6 (optional), 12, and $24 \mathrm{~h}$ and then every $24 \mathrm{~h}$ after the first day. The carboys were stirred manually every $3 \mathrm{~h}$ during the experiments to keep particles from settling. Water was processed immediately in the laboratory to measure nutrients $\left(\mathrm{NH}_{4}{ }^{+}, \mathrm{NO}_{3}{ }^{-}+\mathrm{NO}_{2}{ }^{-}, \mathrm{SRP}, \mathrm{Si}\right)$, chlorophyll $a$, high-performance liquid chromatography pigments, phytoplankton counts, and suspended particulate matter (SPM). Chlorophyll $a$ was measured within $3 \mathrm{~h}$ after processing. The experiments lasted 3 to 8 days and ended when chlorophyll $a$ started to decrease or showed no increase from previous day.

\section{Temperature and Solar Radiation}

The water temperature in the incubators and ambient water was measured every $3 \mathrm{~h}$. The incident solar radiation and photosynthetically active radiation were recorded by the environmental monitoring station at the LUMCON marine center (http://weather.lumcon.edu/). Light intensity was measured (LI-COR Inc LI-189 Photometer \& LI-193SA Sensor) at the beginning of each experiment below the surface water with and without screens to make sure that the light intensity was reduced to about 50\% after screening.

\section{Nutrients}

Samples for nutrient measurements were filtered through $0.2-\mu \mathrm{m}$ pore size polycarbonate filters and immediately frozen for later analysis. The concentration of dissolved forms of nitrogen, phosphorus, and silica were analyzed using a Lachat Quick-Chem 8000 Flow Injection Analyzer, using the Lachat Methods approved by USEPA: method 31-107-06-1-B for ammonium, method 31-107-04-1-C for nitrate/nitrite, method 31-115-01-1-H for phosphate, and method 31-114-27-1-C for silicate. 


\section{Chlorophyll $a$}

Water for chlorophyll $a$ analysis was filtered through Whatman $\mathrm{GF} / \mathrm{F}$ filters $(0.45 \mu \mathrm{m})$. The filters were fixed in $5 \mathrm{ml}$ of dimethyl sulfoxide- $90 \%$ acetone ( $40: 60$ by volume) and allowed to extract for at least $2 \mathrm{~h}$ in the dark (Lohrenz et al. 1999). The extracts were measured on a Turner Model 10 fluorometer before and after acidification with $10 \% \mathrm{HCl}$ (Parsons et al. 1984). The fluorometer was calibrated for chlorophyll $a$ against a chemical supply house chlorophyll $a$ standard measured on a spectrophotometer.

\section{Suspended Particulate Matter}

Samples for the determination of SPM were filtered through preweighed $\mathrm{GF} / \mathrm{F}$ filters $(0.45 \mu \mathrm{m})$ that had been precombusted at $450^{\circ} \mathrm{C}$ for $12 \mathrm{~h}$. After filtration, the filters were first dried at $40^{\circ} \mathrm{C}$ to $60^{\circ} \mathrm{C}$ for $24 \mathrm{~h}$ and weighed to determine the total suspended matter. Each filter was then heated to $450^{\circ} \mathrm{C}$ for $12 \mathrm{~h}$ and then reweighed to determine the amount of inorganic and organic suspended matter.

\section{Phytoplankton Identification and Enumeration}

Phytoplankton samples were preserved in $0.5 \%(v / v)$ glutaraldehyde and size-fractionated by filtration onto $0.2-$, $3-$, and $8-\mu \mathrm{m}$ polycarbonate filters. The latter two fractions were stained with $0.03 \%$ proflavine hemisulfate, and the $0.2-$ to $3-\mu \mathrm{m}$ fraction was counted immediately after filtration. The $>8-\mu \mathrm{m}$ fraction was frozen and counted later. All samples were counted using an Olympus BH2RFCA epifluorescence microscope with blue and green excitation light and transmitted light (Dortch et al. 1997). All algae were identified to the lowest level possible. The unidentified diatoms were separated as three size fractions $(<10,10-20$, and $>20 \mu \mathrm{m})$. The detection limit was approximately 500 to 1,000 cells per liter and depended on the volume filtered. The volume of water filtered for phytoplankton counting varied from 2 to $25 \mathrm{ml}$. Biovolumes were calculated based on microscopic measurements of dimensions and geometric models of phytoplankton (Hillebrand et al. 1999).

\section{Statistical Analysis and Nutrient Deficiency Calculation}

Because Si did not show any effect on chlorophyll $a$ concentration among all experiments, a two-way analysis of variance was performed for each sampling date to compare chlorophyll $a$ among different $\mathrm{N}$ and $\mathrm{P}$ treatments and controls (SAS Institute Incorporated 2003). When significant effects of nutrient treatments were observed relative to the controls, a hierarchical logic sequence similar to the one in Maberly et al. (2002) and James et al. (2003) was used to determine which nutrient was the most limiting to algal growth.

The $\mathrm{N}$ and $\mathrm{P}$ deficiencies ( $\mathrm{N} d e f$ and $\mathrm{P} d e f$ ) were calculated by the following equations:

$\mathrm{N} d e f=(\mathrm{BNP}-\mathrm{BP}) / \mathrm{BC}$

and

$\mathrm{P} d e f=(\mathrm{BNP}-\mathrm{BN}) / \mathrm{BC}$

where BNP is the mean of peak chlorophyll $a$ in $\mathrm{N}+\mathrm{P}$ treatments; $\mathrm{BP}(\mathrm{BN})$ is the mean of peak chlorophyll $a$ in $+\mathrm{P}$ $(+\mathrm{N})$ treatments, and $\mathrm{BC}$ is the mean of chlorophyll $a$ in controls from the same day of peak chlorophyll $a$ in treatments. The calculation gives the indices of $\mathrm{N}(\mathrm{P})$ deficiency without the confounding effects of $\mathrm{P}(\mathrm{N})$ deficiency (Dodds et al. 2002). The higher values indicate severe nutrient deficiency.

\section{Results}

Water Temperature and Solar Radiation

The water temperature was similar among the incubators and the ambient water during the incubations (Table 2). Water temperature in incubators varied from $20^{\circ} \mathrm{C}$ to low $30^{\circ} \mathrm{C}$ in Jul04, from $9^{\circ} \mathrm{C}$ to $16^{\circ} \mathrm{C}$ in Jan04, between $19^{\circ} \mathrm{C}$ and $26^{\circ} \mathrm{C}$ in Oct03, and $13^{\circ} \mathrm{C}$ to $26^{\circ} \mathrm{C}$ in Apr04. The daytime water temperature varied $3^{\circ} \mathrm{C}$ to $7^{\circ} \mathrm{C}$. The difference between day and night temperatures was usually $2^{\circ} \mathrm{C}$ to $3^{\circ} \mathrm{C}$, except during some cold front passages when the water temperatures could drop about $5^{\circ} \mathrm{C}$ to $6^{\circ} \mathrm{C}$ overnight.

The daylight length ranged from 11 to $13 \mathrm{~h}$, and the highest radiation was usually between 1200 and 1400 (CST). Solar radiation at its peak varied considerably within an incubation and by season (Table 2).

In general, the initial total SPM concentrations were lower in Oct03 and Jul04 than in Jan04 and Apr04, when the DPD was discharging water (Fig. 2), but the percentage of organic matter was higher in Oct03 and Jul04 than in the other seasons (Table 3). The concentration of SPM in Lac des Allemands was generally higher than in the other lakes. The concentration of SPM was higher at the conclusion of the incubation compared to that in the beginning of the experiment, and these changes were attributed to phytoplankton growth, as indicated by elevated percentage of organic matter over the course of the incubation (data not shown). 
Table 2 The physical conditions during the experiments: ambient lake salinity and Secchi disk depth, experiment duration, range of incubator temperature, and range of highest hourly means of solar radiation between 1200 and 1400CST

\begin{tabular}{|c|c|c|c|c|c|c|}
\hline & Experiment & Duration & $\begin{array}{l}\text { Lake Secchi } \\
\quad(\mathrm{m})\end{array}$ & $\begin{array}{l}\text { Lake salinity } \\
\quad(\mathrm{psu})\end{array}$ & $\begin{array}{c}\text { Incubator water temperature } \\
\qquad\left({ }^{\circ} \mathrm{C}\right)\end{array}$ & $\begin{array}{l}\text { Solar radiation } \\
\left(\mathrm{W} \mathrm{m}^{-2}\right)\end{array}$ \\
\hline \multirow[t]{4}{*}{ Cataouatche } & Oct03 & Oct $14-17$ & 1.09 & 0.7 & $21-26$ & $637-835$ \\
\hline & Jan04 & Jan 13-19 & 0.76 & 0 & $10-16$ & $245-667$ \\
\hline & Apr04 & Mar 31-Apr 3 & 1.07 & 0.21 & $18-22$ & $810-934$ \\
\hline & Jul04 & Jun 29-Jul 1 & 1.25 & 0.16 & $28-32$ & $841-1,040$ \\
\hline \multirow[t]{4}{*}{ Salvador } & Oct03 & Oct $21-24$ & 2.32 & 1.1 & $22-25$ & $733-754$ \\
\hline & Jan04 & Jan $21-27$ & 1.01 & 0.02 & $10-16$ & $139-662$ \\
\hline & Apr04 & Apr 6-8 & 0.67 & 0.21 & $20-25$ & $603-905$ \\
\hline & Jul04 & Jul 6-9 & 1.15 & 0.11 & $26-32$ & $225-1,005$ \\
\hline \multirow[t]{4}{*}{ des Allemands } & Oct03 & Oct 29-Nov 2 & 0.98 & 0.1 & $19-26$ & $684-727$ \\
\hline & Jan04 & Feb 4-7 & 0.52 & 0 & $9-16$ & $304-743$ \\
\hline & Apr04 & Apr 13-20 & 0.56 & 0.09 & $13-26$ & $813-957$ \\
\hline & Jul04 & Jul 12-17 & 0.85 & 0.06 & $29-32$ & $625-965$ \\
\hline
\end{tabular}

\section{Chlorophyll $a$}

The Jan04 experiments started after the full operation of the DPD began in December 2003 (Fig. 2) when the initial concentrations of chlorophyll $a$ in the three lakes showed the highest values compared to the same month in previous years (Turner et al. unpublished data). Lake Cataouatche and Lac des Allemands had high chlorophyll $a$ concentrations and low nutrient concentrations; whereas Lake
Salvador had intermediate chlorophyll $a$ concentrations but high nutrient concentrations, especially nitrate (Table 3). We point out that the Lake Salvador water sample was collected when the DPD discharge was relatively high $\left(6.7 \times 10^{6} \mathrm{~m}^{3}\right.$ day $\left.^{-1}\right)$, whereas the Lake Cataouatche water was collected at low discharge of the DPD $\left(1.9 \times 10^{6} \mathrm{~m}^{3}\right.$ day $^{-1}$ ).

The changes in chlorophyll $a$ concentration in response to $\mathrm{N}$ additions were different for all experiments and all

Table 3 The initial concentration of chlorophyll $a(\mathrm{Chl} a)$, SPM, nutrients in lake waters, and the added nutrients in the bioassay experiments

\begin{tabular}{|c|c|c|c|c|c|c|c|c|c|c|}
\hline \multirow[t]{2}{*}{ Experiments } & & \multicolumn{7}{|c|}{ Initial concentration } & \multirow{2}{*}{$\begin{array}{l}\text { Probable }^{\mathrm{a}} \\
\text { nutrient limitation }\end{array}$} & \multirow{2}{*}{$\begin{array}{l}\text { Added nutrients } \\
\mathrm{NO}_{3}{ }^{-} \text {to } \mathrm{PO}_{4}{ }^{3-} \text { to } \mathrm{Si} \\
\text { (Molar) }\end{array}$} \\
\hline & & $\begin{array}{l}\text { Chla } \\
\mu \mathrm{g} 1^{-1}\end{array}$ & $\begin{array}{l}\mathrm{SPM} \\
\mathrm{mg} \mathrm{1^{-1 }}\end{array}$ & $\begin{array}{l}\mathrm{NO}_{3+2} \\
(\mu \mathrm{M})\end{array}$ & $\mathrm{NH}_{4}^{+}$ & SRP & $\mathrm{Si}$ & $\begin{array}{l}\text { DIN to SRP } \\
\text { (Molar) }\end{array}$ & & \\
\hline \multirow[t]{4}{*}{ Cataouatche } & Oct03 & 8.4 & $5(67 \%)$ & 0.8 & 1.7 & 1.1 & 76 & 2.3 & $\mathrm{~N}$ & $32: 2: 32$ \\
\hline & Jan04 & 44 & $23(49 \%)$ & 1.6 & 0.6 & 0.2 & 30 & 11 & $\mathrm{P}$ & $96: 6: 96$ \\
\hline & Apr04 & 6.7 & $8(44 \%)$ & 0.1 & 4.9 & 0.2 & 16 & 25 & $P$ & $24: 1.5: 24$ \\
\hline & Jul04 & 10 & $12(53 \%)$ & 0.1 & 1.2 & 0.3 & 86 & 4 & $\mathrm{~N}$ & $40: 2.5: 40$ \\
\hline \multirow[t]{4}{*}{ Salvador } & Oct03 & 3.9 & 3 (ND) & 0.4 & 1.2 & 0.9 & 80 & 1.8 & $\mathrm{~N}$ & $16: 1: 16$ \\
\hline & Jan04 & 8.6 & $21(26 \%)$ & 27 & 1.5 & 1.4 & 73 & 20 & None & $32: 2: 32$ \\
\hline & Apr04 & 23 & $9(39 \%)$ & 2.7 & 1.0 & 0.2 & 29 & 18 & $P$ & $72: 4.5: 72$ \\
\hline & Jul04 & 5.9 & $4(67 \%)$ & 0.1 & 0.7 & 1.4 & 65 & 0.6 & $\mathrm{~N}$ & $32: 2: 32$ \\
\hline \multirow[t]{4}{*}{ des Allemands } & Oct03 & 26 & $15(59 \%)$ & 1.4 & 23 & 1.2 & 29 & 20 & None & $96: 6: 96$ \\
\hline & Jan04 & 166 & $66(42 \%)$ & 2.5 & 1.5 & 0.1 & 34 & 40 & $P$ & $128: 8: 128$ \\
\hline & Apr04 & 17 & $15(32 \%)$ & 3 & 25 & 1.0 & 21 & 28 & None & $72: 4.5: 72$ \\
\hline & Jul04 & 23 & $7.6(84 \%)$ & 3 & 2 & 3.3 & 141 & 1.5 & $\mathrm{~N}$ & $80: 5: 80$ \\
\hline
\end{tabular}

$\mathrm{NO}_{3+2}: \mathrm{NO}_{3}{ }^{-}+\mathrm{NO}_{2}{ }^{-}$. Data in parentheses are the percentages of the organic fraction in the suspended particulate matter

$N D$ no data

${ }^{a}$ Nutrient limitation follows the nutrient criteria of Dortch and Whitledge (1992): N limitation: DIN $\leq 1.0 \mu \mathrm{M}$, DIN to SRP $<10$ (molar basis); $\mathrm{P}$ limitation: $\mathrm{SRP} \leq 0.2 \mu \mathrm{M}$, DIN to $\mathrm{SRP}>30$ 
lakes (Figs. 3, 4, and 5; Table 4). There were five experiments (Figs. 3 (a), 4 (a, d), 5 (a, d)), when the concentration of chlorophyll $a$ increased significantly after $\mathrm{N}$ additions (i.e., after $+\mathrm{N}, \mathrm{N}+\mathrm{P}, \mathrm{N}+\mathrm{Si}$, and + All additions). The degree of $\mathrm{N}$ deficiency was more than ten times higher than $\mathrm{P}$ deficiency in these five experiments (Table 4). Meanwhile, the additions of $+\mathrm{Si},+\mathrm{P}$, and $\mathrm{Si}+\mathrm{P}$ did not result in an increase in chlorophyll $a$, so we conclude that $\mathrm{N}$ was the only limiting nutrient for phytoplankton growth in these five experiments. In the Jul04 experiment of Lac des Allemands (Fig. 5 (d)), the effect of the $\mathrm{N}$ addition was to raise the chlorophyll $a$ concentration in the first 3 days, and then the difference between the chlorophyll $a$ in control and non- $\mathrm{N}$ treatments
Fig. 3 The concentration of chlorophyll $a$ in all treatments (left panels) and dissolved inorganic nitrogen (DIN) and soluble reactive phosphorus (SRP) in the treatments of $+\mathrm{N}$, $+\mathrm{N}+\mathrm{P}$, and + All $(\mathrm{N}+\mathrm{P}+\mathrm{Si}$; right panels) throughout the experiments with Lake Cataouatche water. The data are averages of duplicate samples. Note: labels of DIN axis are descending in correspondence to incubation time in chlorophyll $a$ panels. Solid line in right panels indicates Redfield ratio (DIN to $\mathrm{SRP}=16: 1$ )
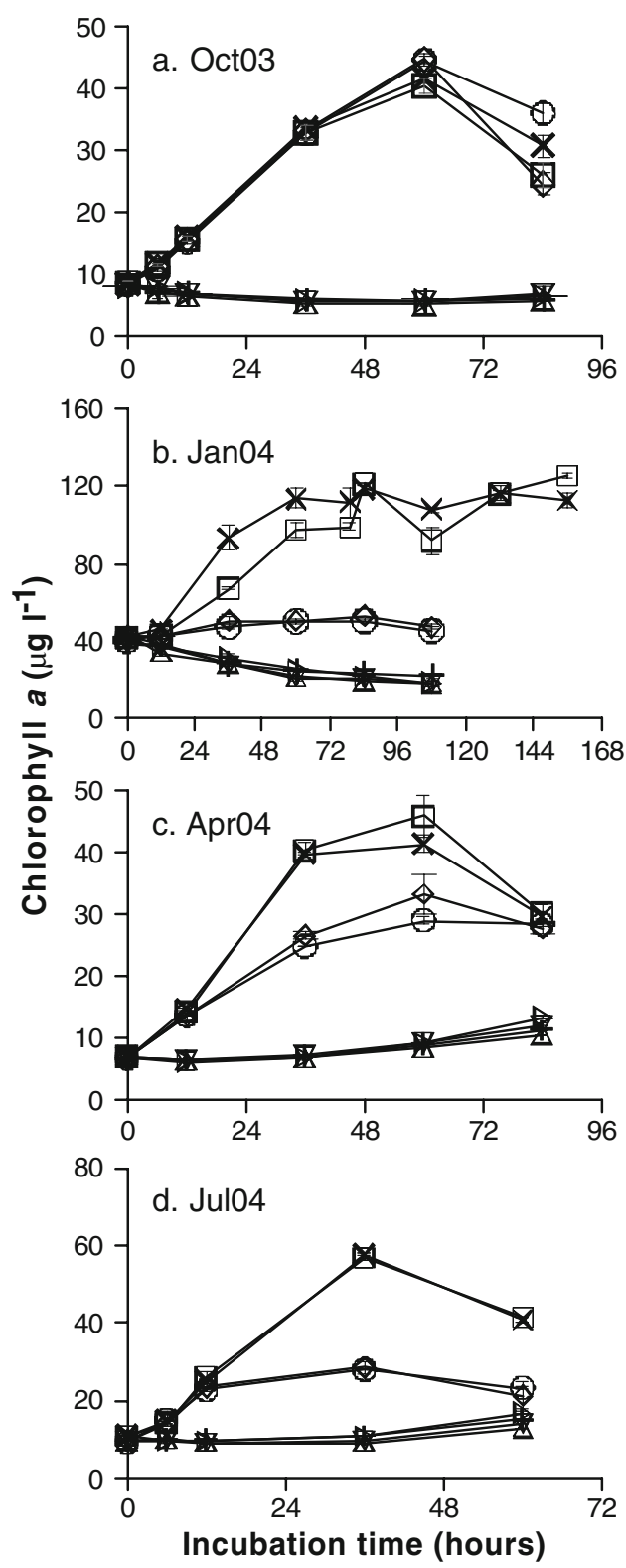
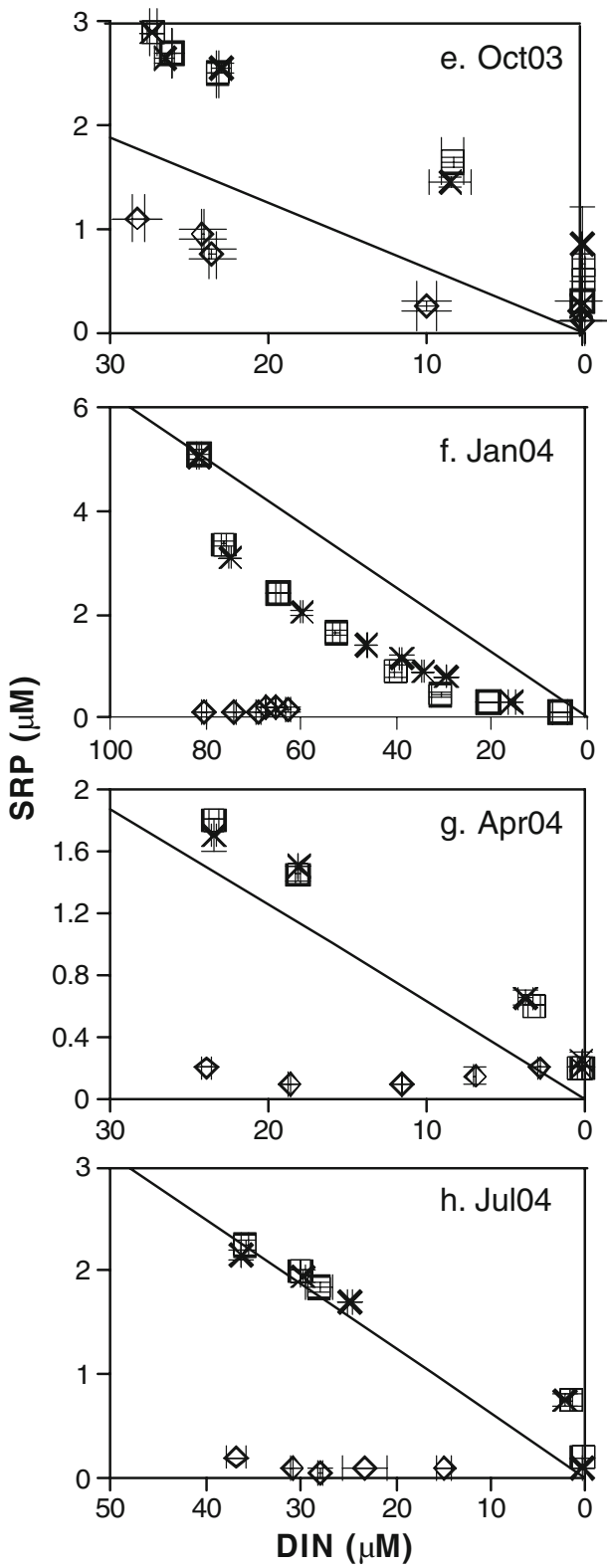

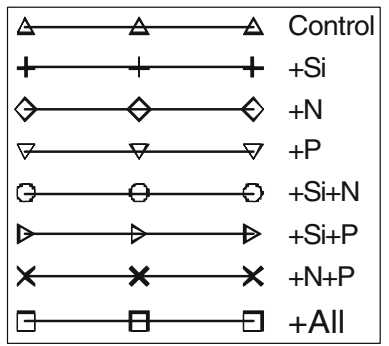


Fig. 4 The concentration of chlorophyll $a$ in all treatments (left panels) and dissolved inorganic nitrogen (DIN) and soluble reactive phosphorus (SRP) in the treatments of $+\mathrm{N}$, $+\mathrm{N}+\mathrm{P}$, and $+\mathrm{All}(\mathrm{N}+\mathrm{P}+\mathrm{Si}$; right panels) throughout the experiments with Lake Salvador water. The data are averages of duplicate samples. Note: labels of DIN axis are descending in correspondence to incubation time in chlorophyll $a$ panels. Solid line in right panels indicates Redfield ratio (DIN to $\mathrm{SRP}=16: 1)$
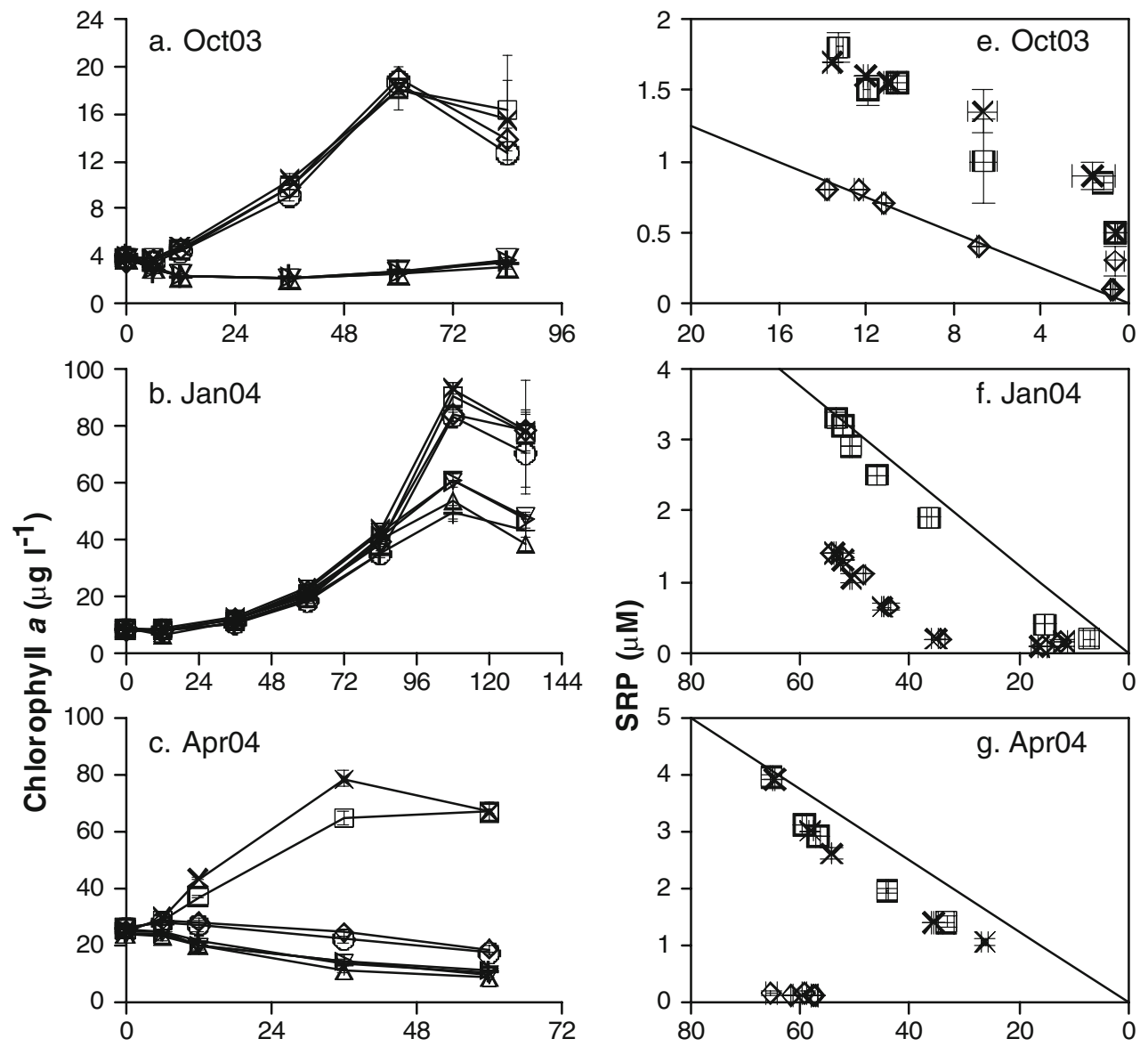

ณ 5
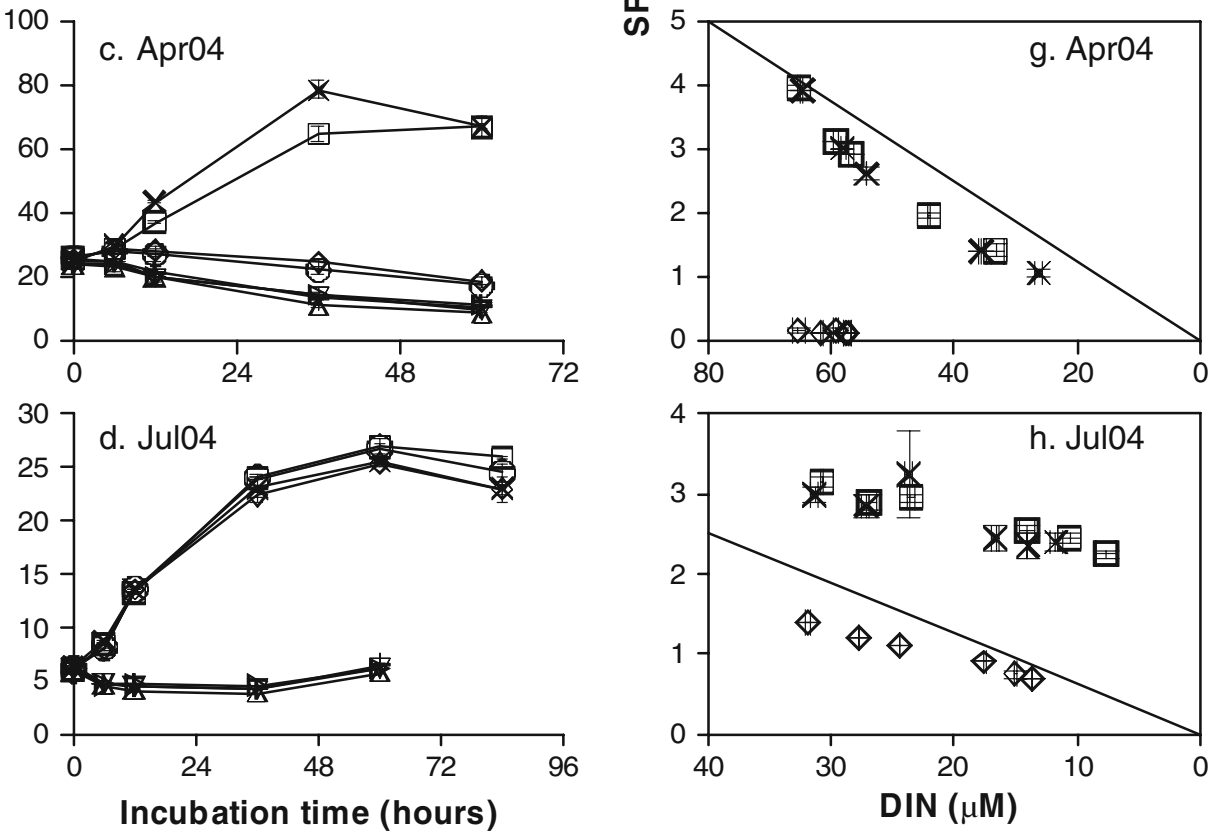

declined. We conclude that phytoplankton growth in the other five experiments (Figs. 3 (b-d), 4 (c), and 5 (c)) was limited both by $\mathrm{N}$ and $\mathrm{P}$ but much more strongly by $\mathrm{N}$ than $\mathrm{P}$ because the $\mathrm{P}$ addition alone did not stimulate additional growth and because the chlorophyll $a$ concentration in the treatments with the $\mathrm{N}+\mathrm{P}$ addition was significantly higher than in treatments receiving only the $\mathrm{N}$ addition. The $\mathrm{N}$ deficiency degree in these five experiments showed slightly higher Ndef/Pdef (1.2 to 3) than P deficiency (Table 4). There are two experiments where the addition of $+\mathrm{P}$ 
Fig. 5 The concentration of chlorophyll $a$ in all treatments (left panels) and dissolved inorganic nitrogen (DIN) and soluble reactive phosphorus (SRP) in the treatments of $+\mathrm{N}$, $+\mathrm{N}+\mathrm{P}$, and + All $(\mathrm{N}+\mathrm{P}+\mathrm{Si}$; right panels) throughout the experiments with Lac des Allemands water. The data are averages of duplicate samples. Note: labels of DIN axis are descending in correspondence to incubation time in chlorophyll $a$ panels. Solid line in right panels indicates Redfield ratio (DIN to $\mathrm{SRP}=16: 1)$ resulted in an elevated chlorophyll $a$ level compared to that in the controls (Figs. 4 (b) and 5 (b)), but the significance $(p=0.03)$ was less compared to that in the $+\mathrm{N}$ microcosms $(p<0.001$, Table 4$)$. The degree of $\mathrm{N}$ and $\mathrm{P}$ deficiency was both low, but $\mathrm{N}$ deficiency was relatively higher than $\mathrm{P}$
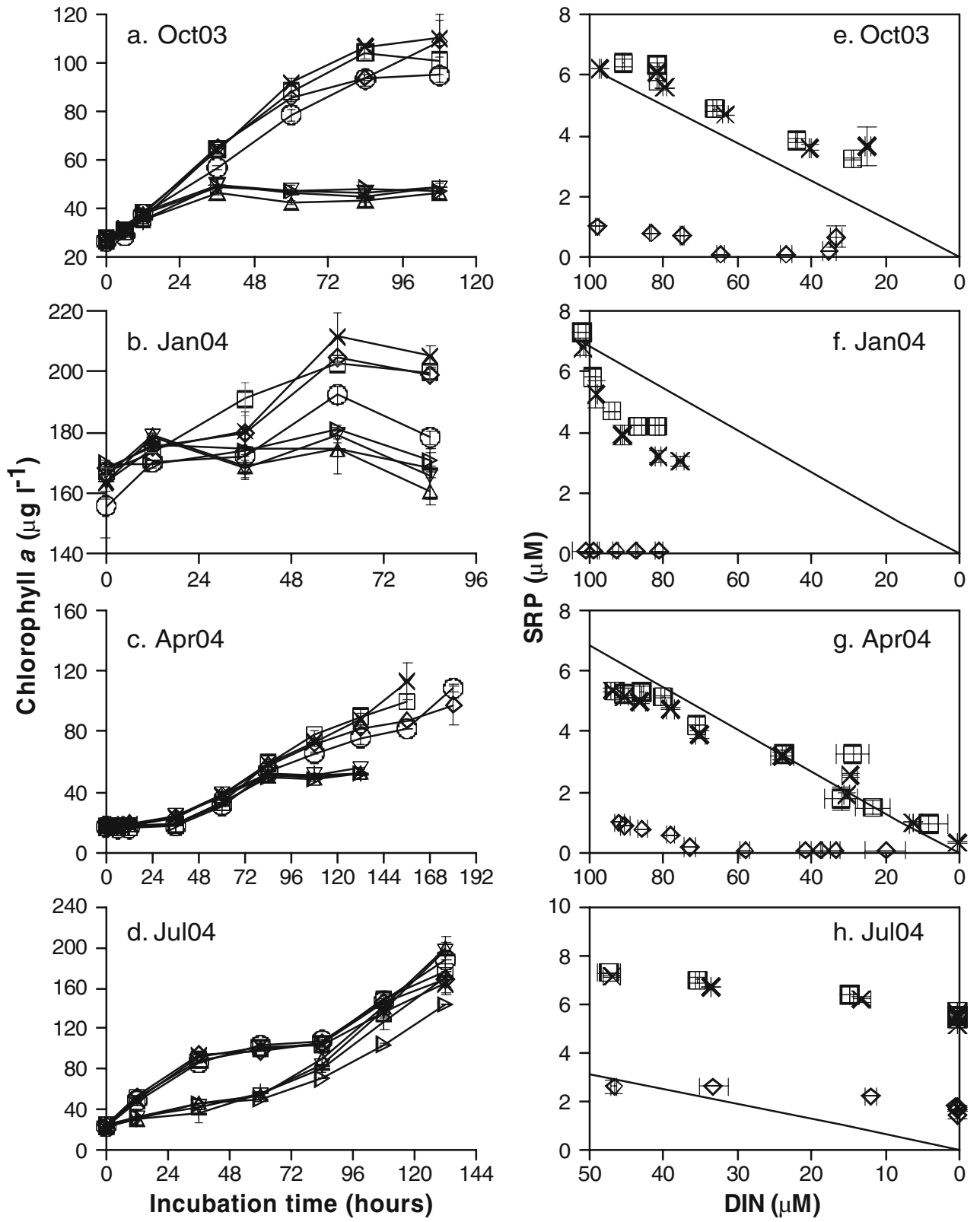

deficiency by three and five times, respectively. The chlorophyll $a$ concentration in the $\mathrm{N}+\mathrm{P}$ addition microcosm was similar to that in the $+\mathrm{N}$ microcosm and significantly greater than in the $+\mathrm{P}$ microcosm. The phytoplankton growth in these two microcosms was, 
Table 4 Summary of chlorophyll $a$ responses to nutrient additions and the results of nutrient limitation from bioassays

\begin{tabular}{|c|c|c|c|c|c|c|c|c|c|c|c|c|}
\hline \multirow[t]{2}{*}{ Experiments } & & \multirow{2}{*}{$\begin{array}{l}+\mathrm{N}> \\
\text { control }\end{array}$} & \multirow{2}{*}{$\begin{array}{l}+\mathrm{P}> \\
\text { control }\end{array}$} & \multirow{2}{*}{$\begin{array}{l}+\mathrm{Si}> \\
\text { control }\end{array}$} & \multirow{2}{*}{$\begin{array}{l}+\mathrm{N}> \\
+\mathrm{P}\end{array}$} & \multirow{2}{*}{$\begin{array}{l}+\mathrm{P}> \\
+\mathrm{N}\end{array}$} & \multirow{2}{*}{$\begin{array}{l}+\mathrm{N}+\mathrm{P}> \\
+\mathrm{N}\end{array}$} & \multirow{2}{*}{$\begin{array}{l}+\mathrm{N}+\mathrm{P}> \\
+\mathrm{P}\end{array}$} & \multirow[t]{2}{*}{ Limitation } & \multicolumn{3}{|c|}{ Nutrient deficiency } \\
\hline & & & & & & & & & & $\mathrm{N} d e f$ & $\mathrm{P} d e f$ & $\begin{array}{l}\mathrm{N} d / \\
\mathrm{P} d\end{array}$ \\
\hline \multirow[t]{4}{*}{ Cataouatche } & Oct03 & $\mathrm{y}$ & - & - & $\mathrm{y}$ & - & - & $\mathrm{y}$ & $\mathrm{N}$ & 6.9 & 0.6 & 12 \\
\hline & Jan04 & $\mathrm{y}$ & - & - & $\mathrm{y}$ & - & $\mathrm{y}$ & $\mathrm{y}$ & $\mathrm{N}+\mathrm{P}$ & 4.9 & 3.2 & 1.5 \\
\hline & Apr04 & $\mathrm{y}$ & - & - & $\mathrm{y}$ & - & $\mathrm{y}$ & $\mathrm{y}$ & $\mathrm{N}+\mathrm{P}$ & 3.5 & 0.9 & 3.5 \\
\hline & Jul04 & $\mathrm{y}$ & - & - & $\mathrm{y}$ & - & $\mathrm{y}$ & $\mathrm{y}$ & $\mathrm{N}+\mathrm{P}$ & 5.2 & 3.2 & 1.6 \\
\hline \multirow[t]{4}{*}{ Salvador } & Oct03 & $\mathrm{y}$ & - & - & $\mathrm{y}$ & - & - & $\mathrm{y}$ & $\mathrm{N}$ & 6.2 & 0.4 & 16 \\
\hline & Jan04 & $\mathrm{y}$ & $\mathrm{y}^{*}$ & - & $\mathrm{y}$ & - & - & $\mathrm{y}$ & $\mathrm{N}, \mathrm{P}$ & 0.6 & 0.2 & 3 \\
\hline & Apr04 & $\mathrm{y}$ & - & - & $\mathrm{y}$ & - & $\mathrm{y}$ & $\mathrm{y}$ & $\mathrm{N}+\mathrm{P}$ & 6.1 & 5.1 & 1.2 \\
\hline & Ju104 & $\mathrm{y}$ & - & - & $\mathrm{y}$ & - & - & $\mathrm{y}$ & $\mathrm{N}$ & 5.6 & 0.04 & 140 \\
\hline \multirow{4}{*}{$\begin{array}{l}\text { des } \\
\text { Allemands }\end{array}$} & Oct03 & $\mathrm{y}$ & - & - & $\mathrm{y}$ & - & - & $\mathrm{y}$ & $\mathrm{N}$ & 1.3 & 0.02 & 65 \\
\hline & Jan04 & $\mathrm{y}$ & $\mathrm{y}^{*}$ & - & $\mathrm{y}$ & - & - & $y$ & $\mathrm{~N}, \mathrm{P}$ & 0.2 & 0.04 & 5 \\
\hline & Apr04 & $\mathrm{y}$ & - & - & $\mathrm{y}$ & - & $\mathrm{y}$ & $\mathrm{y}$ & $\mathrm{N}+\mathrm{P}$ & 1.1 & 0.3 & 3.4 \\
\hline & Jul04 & $\mathrm{y}$ & - & - & $\mathrm{y}$ & - & - & $y$ & $\mathrm{~N}$ & 0.9 & 0.07 & 12 \\
\hline
\end{tabular}

Listed are comparisons of chlorophyll $a$ between the controls and different treatments

$+\mathrm{N}$ N addition, $+\mathrm{P}$ P addition, $+\mathrm{N}+\mathrm{P} \mathrm{N}$ and $\mathrm{P}$ addition, $y$ a statistically significant difference between treatments at $P<0.05,-$ no significant difference, Nutrient limitation: $\mathrm{N}$ nitrogen limitation, $\mathrm{N}+\mathrm{P} \mathrm{N}$ and $\mathrm{P}$ colimitation, $\mathrm{N}, \mathrm{P}$ firstly $\mathrm{N}$ and secondarily $\mathrm{P}$ limitation, $\mathrm{N} d e f \mathrm{~N}$ deficiency, $\mathrm{P} d e f \mathrm{P}$ deficiency, $\mathrm{N} d / \mathrm{P} d$ ratio of $\mathrm{N}$ deficiency to $\mathrm{P}$ deficiency

${ }^{*} p=0.03$, most of $p$ values $<0.01$ except at this level

therefore, considered to be limited primarily by $\mathrm{N}$ and secondarily by P. Microcosms receiving a silicate addition showed no significant effects on chlorophyll $a$ concentrations for all the experiments.

\section{Nutrients}

The initial concentration of DIN $\left(\mathrm{NO}_{3+2}+\mathrm{NH}_{4}{ }^{+}\right)$and SRP in three lakes was generally low, $\leq 5$ and $<1.5 \mu \mathrm{M}$, respectively, in most seasons, while that of $\mathrm{Si}$ varied between 16 and $140 \mu \mathrm{M}$ (Table 3). The change in nutrient concentrations is what is expected when the chlorophyll $a$ concentrations change as described in the previous section. In general, when chlorophyll $a$ concentration remained flat over the experiments, e.g., in the control microcosms and in those with $+\mathrm{P}$ and/or $+\mathrm{Si}$, then the concentration of DIN was much lower than $1.0 \mu \mathrm{M}$, and the concentration of SRP and $\mathrm{Si}$ did not change compared to the initial concentrations. But, in other treatments, particularly with $+\mathrm{N}$ additions, the concentration of DIN, SRP, and Si decreased over the experiments when the chlorophyll $a$ concentration increased (plots not shown). Because the concentration of Si remained generally $>2 \mu \mathrm{M}$ until the end of the experiments, and the $+\mathrm{Si}$ alone did not affect chlorophyll $a$ concentration in any of the experiments, the concentrations of DIN and SRP in the treatments of $+\mathrm{N},+\mathrm{N}+\mathrm{P}$ and + All were plotted against each other to illustrate nitrogen and phosphorus uptake during phytoplankton growth in the microcosms (Figs. 3, 4, and 5). The uptake ratios of DIN to SRP, calculated from the correlation from DIN and SRP, decreased over the experiments and are summarized in Tables 5 and 6 . These results support the conclusion from the bioassays that $\mathrm{N}$ was becoming scarce, relative to $\mathrm{P}$.

The concentration of DIN and SRP in treatments with $+\mathrm{N}+\mathrm{P}$ and + All decreased linearly over time in most experiments. The uptake ratios of DIN to SRP were mostly close to the Redfield molar ratio (12 to 24), except that they were higher in the July experiments (23 to 28 ; Table 5). The concentration of DIN and SRP in the $+\mathrm{N}$ treatments also decreased until SRP was depleted in the Oct03 experiment in Lake Cataouatche (Fig. 3 (e)), the Oct03, Jan04, and Jul04 Lake Salvador experiment (Fig. 4 (e-f, h)), and the Jul04 Lac des Allemands experiment (Fig. 5 (h)). The decrease in SRP concentration, however, was less compared to the decline in DIN concentration, so that the uptake ratio of DIN to SRP was higher than those with both $\mathrm{N}+\mathrm{P}$ addition (Table 5).

Plots of the concentrations of DIN and SRP in the Jan04 Lake Cataouatche experiment (Fig. 3 (f)), the Apr04 Lake Salvador experiment (Fig. 4 (g)), and the Jan04 Lac des Allemands experiment (Fig. 5 (f)) also demonstrated that there was a phosphorus "sink" in the sense that the DIN and SRP concentration decreased relative to the Redfield ratio. The initial SRP concentration in the three experiments was as low as 0.1 to $0.2 \mu \mathrm{M}$ (Table 3). The uptake ratio of DIN to $\mathrm{SRP}$ on the first day after $\mathrm{N}$ and $\mathrm{P}$ addition was as low as 2:3 
Table 5 A summary of the DIN to SRP uptake ratios (molar) from the correlation of DIN and SRP in the experiments $(p<0.01$, unless noted) with water from the three lakes

(Figs. 3, 4, and 5)

The uptake ratios of "nonlinear" correlation are given in Table 6 $n / a$ not applicable (used when the concentration of $\mathrm{PO}_{4}^{-3}$ was close to the threshold value $(0.2 \mu \mathrm{M})$ and did not change over the experiment)

\begin{tabular}{llllll}
\hline Lake & Treatment & Oct03 & Jan04 & Apr04 & Jul04 \\
\hline Cataouatche & $+\mathrm{N}$ & 21 & $\mathrm{n} / \mathrm{a}$ & $\mathrm{n} / \mathrm{a}$ & $\mathrm{n} / \mathrm{a}$ \\
& $+\mathrm{N}+\mathrm{P}$ & 14 & Nonlinear & 16 & 24 \\
& $+\mathrm{All}$ & 13 & Nonlinear & 15 & 23 \\
Salvador & $+\mathrm{N}$ & 21 & 16 & $\mathrm{n} / \mathrm{a}$ & 28 \\
& $+\mathrm{N}+\mathrm{P}$ & 12 & 15 & Nonlinear & $26(p=0.07)$ \\
& $+\mathrm{All}$ & 12 & $\mathrm{n} / \mathrm{a}$ & Nonlinear & 28 \\
des Allemands & $+\mathrm{N}$ & 40 & n/a & 26 & $45(p=0.01)$ \\
& $+\mathrm{N}+\mathrm{P}$ & 24 & Nonlinear & 18 & 26 \\
& + All & 19 & Nonlinear & 18 & 26 \\
\hline
\end{tabular}

and increased quickly close to the Redfield ratio by the third day (Table 6).

\section{Phytoplankton Composition}

The biovolume of major phytoplankton groups varied seasonally in the three lakes (Fig. 6). The majority of phytoplankton in Lake Cataouatche and Salvador were diatoms in most months. The biovolume percentage of cyanobateria was highest in summer, reaching 50\% in Lake Cataouatche. The phytoplankton communities in Lac des Allemands were dominated by cyanobacteria in all seasons and were $53 \%$ to $96 \%$ of the total biovolume. Diatoms were composed mainly of centrics, such as Cyclotella spp., Aulacoseira spp., Stephanodiscus spp. and Skeletonema spp. The main cyanobacteria in these three lakes included the heterocystous and potentially toxic cyanobacteria Anabaena spp., Anabaenopsis spp., Cylindrospermopsis raciborskii, and Aphanizomenon spp. The latter three taxa were periodically detected in all three lakes, whereas Anabaena spp. were usually the major cyanobacteria in all seasons in Lake Salvador $\left(10^{4}\right.$ to $10^{5}$ cells per liter) and Lac des Allemands $\left(10^{6}\right.$ to $10^{8}$ cells per liter) and summer in Lake Cataouatche $\left(10^{6}\right.$ to $10^{7}$ cells per liter $)$. The concentration of Microcystis spp., another potential toxin producer, was high $\left(10^{7}\right.$ to $10^{8}$ cells per liter $)$ in Lac des Allemands and at lower levels $\left(10^{5}\right.$ to $10^{6}$ cells per liter $)$ in summer in the other lakes. Cryptophytes occupied $20 \%$ to $36 \%$ of the total biovolume. The percentage of chlorophytes in October reached $10 \%$ to $20 \%$ of the total biovolume. Commonly seen chlorophytes in the three lakes included Scenedesmus spp., Closterium spp., Chlorella spp., Actinastrum spp., and Pediastrum spp. Euglenoids and freshwater dinoflagellates were detected at moderate densities $\left(10^{4}\right.$ to $10^{5}$ and $10^{3}$ to $10^{4}$ cells per liter, respectively).

\section{Discussion}

Phytoplankton growth is often considered to be primarily limited by $\mathrm{P}$ in freshwater lakes and by $\mathrm{N}$ in estuarine and coastal areas (Schindler 1977; Hecky and Kilham 1988; Schindler et al. 2008); however, this dichotomy is oversimplistic (Rabalais 2002; Conley et al. 2009). Controlling $\mathrm{P}$ loading has been a major management objective in freshwater lakes (e.g., Schindler et al. 2008). However, phosphorus limitation has been found in coastal areas (Turner et al. 1990; Fujiki et al. 2004; Sylvan et al. 2006) and a gradient with nitrogen limitation in estuaries (e.g., Elmgren 2001; Paerl et al. 2004). The distinction between the nutrients limiting phytoplankton growth in freshwater and marine systems may not be useful if it is based on a stoichiometric analysis of dissolved constituents (Guildford and Hecky 2000). Elser et al. (1990) reviewed the results of North American freshwater bioassays and found that phytoplankton growth was much more frequently enhanced by the combination of $\mathrm{N}+\mathrm{P}$ enrichments than by either $\mathrm{N}$ or $\mathrm{P}$ additions alone. Recently, there is increasing evidence from bioassay experiments indicating that nitrogen is often a limiting and/or colimiting factor of phytoplankton production in lakes (Diaz and Pedrozo 1996; Levine and
Table 6 Daily uptake ratio of DIN to SRP in the first 3 days of the experiments when the correlation between DIN and SRP was nonlinear in Table 5

\begin{tabular}{|c|c|c|c|c|c|c|}
\hline & \multicolumn{2}{|c|}{ Jan04, L. Cataouatche } & \multicolumn{2}{|c|}{ Apr04, L. Salvador } & \multicolumn{2}{|c|}{ Jan04, L. des Allemands } \\
\hline & $+\mathrm{N}+\mathrm{P}$ & + All & $+\mathrm{N}+\mathrm{P}$ & + All & $+\mathrm{N}+\mathrm{P}$ & + All \\
\hline Day 1 & 3 & 3 & 7 & 7 & 2 & 2 \\
\hline Day 2 & 14 & 12 & 10 & 13 & 5 & 5 \\
\hline Day 3 & 20 & 16 & 16 & 13 & 14 & 14 \\
\hline
\end{tabular}


Fig. 6 Initial composition of phytoplankton (biovolume percentage) in the experiments
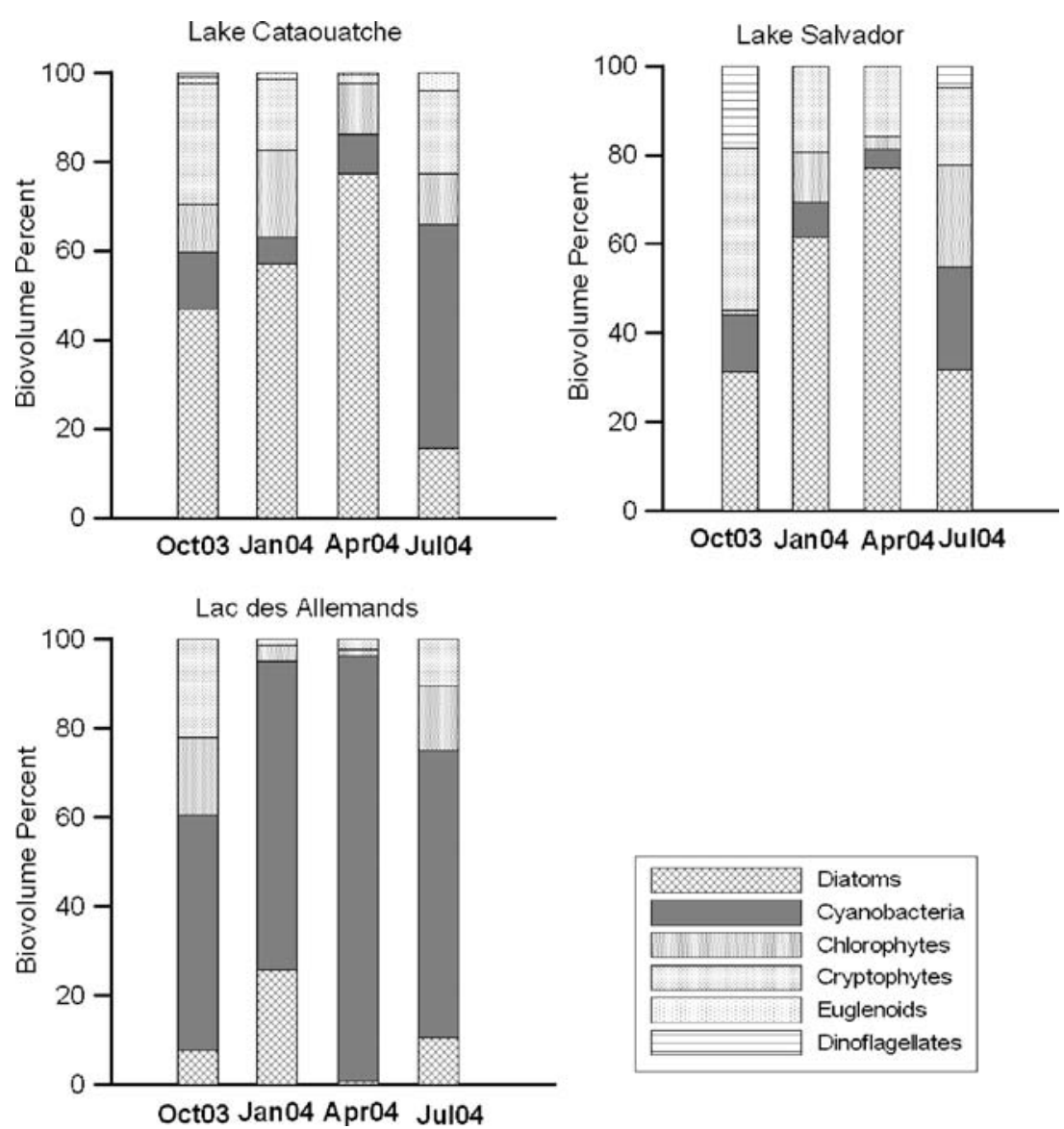

Whalen 2001; Maberly et al. 2002; James et al. 2003; Dzialowski et al. 2005; Groeger 2007). The lakes in this study are freshwater systems when we sampled them (Table 2). Our hypothesis that $\mathrm{P}$ would be the most limiting nutrient in these lakes was not proven by the bioassays. Instead, this study provides an example of how $\mathrm{N}$ limits phytoplankton growth in coastal lakes that are fresh to brackish. Phosphorus can be another limiting nutrient, but it is a weaker factor compared to $\mathrm{N}$ and may be a secondary limiting nutrient when lake systems are enriched by continuous supply of a high concentration of nitrogen. Our results show that nutrient limitation of phytoplankton growth is independent of the salinity conditions ( 0 to $1.1 \mathrm{psu}$ ) in these lake systems (Table 2). These results support the conclusion in Guildford and Hecky (2000) that $\mathrm{N}$ or $\mathrm{P}$ limitation of algal growth is a result of the nutrient status of a system rather than whether the system is freshwater or brackish. Nutrient loading, rather than in situ nutrient ratios for example, may be a better indicator of nutrient limitation.

The results of nutrient limitations based on nutrient criteria (Table 3) and bioassays (Table 4) are consistent, especially so, when the concentration of $\mathrm{NO}_{3}{ }^{-}$was low and DIN to SRP was very low $(<4)$. The most divergent results from these two methods were when the initial SRP concentration was low. If we applied the criteria used by Dortch and Whitledge (1992) to our experiments, then phytoplankton growth in four experiments may be P-limited (Table 3). The bioassay results, however, showed that $\mathrm{P}$ addition alone did not significantly increase phytoplankton biomass. Nitrogen appeared to be a stronger and primary limiting factor because the chlorophyll $a$ concentration increased more with $\mathrm{N}$ addition than with $\mathrm{P}$ addition. The results are, in fact, more in agreement with nutrient deficiency degree (Table 4). Nitrogen limitation when there is a low concentration of SRP can be explained by the following processes: (1) phytoplankton cell $\mathrm{P}$ storage, (2) internal $\mathrm{P}$ regeneration, (3) use of dissolved organic $\mathrm{P}$ (DOP) as a P source, and (4) P scavenging on cell surfaces. These process are a mechanism by which phytoplankton can continue to grow under the depletion of one nutrient by relying on an intracellular reserve of nutrients. Mesocosm experiments in the German Bight showed that phytoplankton (chlorophyll $a>15 \mu \mathrm{g} \mathrm{l}^{-1}$ ) under phosphate depletion could continue growing for 2 to 3 days at the same rates as that under sufficient ambient $\mathrm{PO}_{4}{ }^{3-}$ (Ren 2002). The continuous growth of algae, however, will lead to a decrease of the nutrient in the cell quota (Parslow et al. 1984). As a result, nutrient enrichments will lead to luxury uptake and nutrient storages in cells, which explains the "P 
sink" observed in three experiments (Fig. 3 (f), 4 (g), and 5 (f), Table 6). Luxury P uptake has been commonly reported for various phytoplankton assemblages (Portielje and Lijklema 1994; Istvanovics et al. 1994; Mateo et al. 2006). On the other hand, it was recently found that phosphate tended to scavenge onto phytoplankton cell surfaces in cultures and in natural assemblages (SanudoWilhelmy et al. 2004) and that the amount of surfaceadsorbed $\mathrm{P}$ in the exponential growth phase could range from $14 \%$ to $57 \%$ of the total cellular P (Fu et al. 2005). Large portions of this $\mathrm{P}$ pool can be internalized rapidly and serve as a cellular P reserve when phosphorus demand is high. Both luxury uptake and surface scavenging would decouple phytoplankton nutrient uptake and their growth. In addition, DOP can be another phosphorus source for algal growth. Studies have shown that DOP could partly support high biomass of phytoplankton in hypereutrophic lakes (Connors et al. 1996). Some cyanobacterial species are able to form and sustain bloom biomasses using cellular phosphorus storage and effective remineralization of organic phosphorus in the system (Vahtera et al. 2007). As a result, the same low concentration of SRP in water column does not necessarily mean the same degree of $\mathrm{P}$ deficiency in phytoplankton cells. When we compare the two experiments of Lake Cataouatche in Jan04 and Apr04, the degree of P deficiency in Apr04 was not as high as that in Jan04 (Table 4), despite the same initial SRP concentration $(0.2 \mu \mathrm{M}$, Table 3$)$. This explains why there was no " $\mathrm{P}$ sink" in the Apr04 experiment, and the DIN concentration in the $+\mathrm{N}$ treatment decreased by $20 \mu \mathrm{M}$ within 4 days, while the concentration of SRP remained at the initial value (Fig. $3(\mathrm{~g})$ ). Therefore, the low concentration of phosphate is a necessary, but insufficient, condition for the conclusive diagnosis of $\mathrm{P}$ limitation in lakes. The applicability of dissolved inorganic $\mathrm{N}$ and $\mathrm{P}$, particularly SRP, as indicators of phytoplankton nutrient limitation in aquatic systems has been questioned recently (Dodds 2003). The concentration of total $\mathrm{N}$ and total $\mathrm{P}$ and their ratios are considered to be a better indicator to diagnose nutrient limitation (Dzialowski et al. 2005; Wang et al. 2005; Dodds 2006). However, there are no DOP and particulate phosphorus data available from our bioassay experiments, and so further speculations are unwarranted.

It may be surprising that $\mathrm{N}$ was found to be the limiting nutrient in Lac des Allemands, especially because its phytoplankton community was often dominated by Anabaena spp. and other $\mathrm{N}$-fixing cyanobacteria. Because $\mathrm{N}$ fixation is usually considered to be an important nitrogen source and to contribute to phosphorus limitation in Nfixing taxa in lakes (Schindler 1977; Howarth et al. 1988), the fact that chlorophyll $a$ concentrations in the control and $+\mathrm{P}$ treatments remained the same over the experiments for Lac des Allemands (Fig. 5 (a-d)) indicates the lack of $\mathrm{N}$ fixation in the water. The ratios of heterocysts to vegetative cells $(\mathrm{H}$ to $\mathrm{V})$ were low (0.02 to 0.05$)$ in comparison to results from other studies ( 0.06 to 0.10 in Lee and Rhee 1999; 0.09 to 0.10 in Teaumroong and Innok 2002), suggesting that Anabaena in Lac des Allemands may have a low capacity to fix nitrogen. The initial concentration of $\mathrm{NH}_{4}{ }^{+}$in Oct03 and Apr04 was high (Table 3), which may have inhibited $\mathrm{N}$ fixation in the upper Barataria Basin (Madden et al. 1988). When $\mathrm{NH}_{4}{ }^{+}$was depleted in the control and other non- $\mathrm{N}$ additions microcosms, the algal biomass stopped increasing (Fig. 5 (a, c)), demonstrating that $\mathrm{N}$ fixation did not occur during the experiments. This may be the case that $\mathrm{N}$ deficiency in the microcosms was not severe enough to trigger $\mathrm{N}$ fixation within the first 3 or 5 days (Fig. $5(\mathrm{a}, \mathrm{c})$ ). There may be another limiting factor, e.g., iron, that limits the growth of diazotrophic cyanobacteria in Lac des Allemands. Iron was found to be a limiting restraint in Lake Erken and the addition of iron increased the growth of diazotrophic cyanobacteria (Hyenstrand et al. 1999). However, the $\mathrm{N}$ fixation rates in these lakes and the role of iron in the development of the phytoplankton communities are unknown. There was evidence of $\mathrm{N}$ fixation in the Jul04 experiment of Lac des Allemands, when the chlorophyll $a$ concentration in the control microcosms continued to increase despite of the low concentration of DIN $(5 \mu \mathrm{M})$ at the beginning of the experiment (Fig. 5 (d)). $\mathrm{N}$ fixation is known as an energetically expensive route for cyanobacterial $\mathrm{N}$ acquisition (Postgate 1998), leading to a substantial loss of photosynthetic energy available to the cell for $\mathrm{C}$ fixation and growth. Nitrogenfixing cyanobacteria tend to use an energetically easier nitrogen resource when the external $\mathrm{N}$ supply is high and, as a result, their growth rates are enhanced under $\mathrm{N}$ enrichment (Fig. 5 (d)).

All three lakes in this study are shallow (Table 1) and are likely to be polymictic. According to the results of Tilzer's (1988) study, the relationship between the euphotic depth $(Z e u)$ and Secchi depth $(Z s)$ can be approximately expressed by $Z e u \sim 5 \bullet \sqrt{Z s}$ in lakes with highly variable chlorophyll $a$ biomass $\left(0.3\right.$ to $\left.35 \mu \mathrm{g} \mathrm{l^{-1 }}\right)$. By using this equation, we calculated a $Z e u$ from $Z s$ (Table 2) in each lake and found that it often exceeded their average depth, indicating that light usually penetrated to the bottom and that light limitation was not likely to be occurring under the conditions of calm weather. Phytoplankton under sufficient light conditions, therefore, will respond rapidly to nutrient additions as shown during these experiments. There were two experiments, Jan04 Lake Salvador and Apr04 Lac des Allemands, when the chlorophyll $a$ biomass stagnated for the first day of the experiments (Figs. 4 (b) and 5 (c)). In both experiments, there was a $5^{\circ} \mathrm{C}$ to $6^{\circ} \mathrm{C}$ drop in water temperature when a cold front crossed the upper Barataria Basin on the day before sample collection and when the 
solar radiation did not change much. We assumed that light limitation did not occur in these experiments because the microcosms were kept on the dock at LUMCON and had no shadow over them during incubation. In the lakes, however, strong winds associated with cold front passages stir up sediments and increase the turbidity as reflected by relatively high SPM and low percentage of organic fractions in the two experiments (Table 3). Light limitation in these lakes may temporarily occur during these storm passages, but light conditions will improve when wind speed decreases. That there is sufficient light in water column of these lakes is corroborated by the observed presence of cyanobacteria such as Anabaena, Microcystis, and Aphanizomenon that require high irradiance compared to other cyanobacterial taxa (Reynolds 1993; Havens et al. 1998).

Our study focused on the relationships between nutrients and phytoplankton growth, using a sampling rate and container that fits within the experimental design deemed adequate in terms of how Parsons (1982) diagrammatically discussed the approximate relationships between aquatic organism life cycles and mesocosm sizes. One possible disadvantage of the experimental design is that it removed a natural source of nutrient regeneration - the sediments. The primary product of nitrogen regeneration in sediments is ammonium. No data were available on nutrient regeneration from sediments for the Barataria Basin. A study in the Northern Gulf of Mexico shows that, in the coastal area influenced by the Mississippi River, ammonium regeneration only accounts for a small fraction of the $\mathrm{N}$ requirement during a bloom (Bode and Dortch 1996). Compared to the high external nitrogen loading from local runoff or from diversion of Mississippi River, the contribution of regenerated $\mathrm{N}$ from the sediments could be minor. Nürnberg (1988) estimated that the internal phosphorus loading from mesotrophic lake sediments varied from 2 to $10 \mathrm{mg} \mathrm{P} \mathrm{m}^{-2}$ $\mathrm{day}^{-1}$. Taking these data into account, the regeneration from sediments is insufficient to support algal growth for 1 day in our experimental microcosms. Even if it might be true that the internal $\mathrm{P}$ supply would contribute meaningfully to the phytoplankton $\mathrm{P}$ uptake, the removal of sediments would have aggravated P limitation in the systems.

The lakes in upper Barataria Basin, particularly Lac des Allemands and Lake Cataouatche, were already eutrophied to some extent (Table 1), and their system metabolisms were heterotrophic according to Madden et al. (1988). The Mississippi River water contains high concentration of nutrients, particularly nitrogen as nitrate, varying seasonally near a mean of $100 \mu \mathrm{M}$ (Turner et al. 2007). The interpretation that we make is that high loadings of Mississippi River water into these lakes may result in massive growth of phytoplankton in the receiving lakes, unless the nutrient concentrations are attenuated by inter- actions with wetlands en route or taken up by increased amounts of floating or emergent macrophytes. The high phytoplankton biomass in Lake Cataouatche in January 2004 (Table 3), for example, was very likely related to the full operation of DPD in December 2003 (Fig. 2).

The presence of undesirable cyanobacterial taxa, such as Anabaena, Microcystis, Aphanizomenon, and Cylindrospermopsis is a concern because they are potential toxin producers (mainly microcystins, nodularin, cylindrospermopsin, anatoxins, and a potential neurotoxin; Chorus and Bartram 1999) and are often seen in the three lakes. Anabaena and Microcystis, in particular, are often found in high abundance in summer in Lake Cataouatche and Lac des Allemands (Madden et al. 1988; Dortch et al. unpublished data; Ren et al. unpublished data). The Mississippi River water input is not likely to change nutrient stoichiometry in the lakes in the short term because the molar ratio of DIN to ortho-P to $\mathrm{Si}$ in the Mississippi River is about 16:1:16 (Turner et al. 2007) and phytoplankton uptake ratios of DIN to SRP in the lakes were close to this value (Table 5). When the DPD is operated at low discharges or shut down, however, the retention time of lake waters increases and large phytoplankton blooms will probably occur after light conditions improve. When that happens, a high biomass of algal growth will quickly exhaust the DIN and SRP in water column. Taking the Jan04 and Apr04 experiments of Lake Cataouatche as examples, the concentration of $\mathrm{NO}_{3+2}$ and SRP were low (Table 3) despite the DPD opening being operated at median discharge rates (Fig. 2). Nitrogen limitation in the lakes is evident from the experiments both before and after the full opening of the DPD in December 2003. Furthermore, light condition in lakes can be reduced due to increasing phytoplankton self-shading and SPM loadings from the Mississippi Rivers. Low DIN to SRP ratios and low light favor the growth of heterocystous cyanobacteria, and $\mathrm{N}$ limitation may encourage the growth of $\mathrm{N}$-fixing cyanobacterial taxa (Levine and Schindler 1999). Cyanobacteria have a competitive advantage in lakes which are turbid due to dense biomass of other phytoplankton (Chorus and Bartram 1999). Diatoms and other phytoplankton may experience light limitation, whereas some cyanobacteria taxa such as Anabaena, Microcystis, and Aphanizomenon, on the other hand, have selective advantages because of buoyancy regulated by gas vesicles (Walsby et al. 1997).

The results of these bioassays show that the phytoplankton growth in the lakes in upper Barataria Basin are primarily $\mathrm{N}$-limited, that $\mathrm{P}$ colimitation occurs, and that, when it does, $\mathrm{P}$ is a secondary limiting nutrient. Our results indicate that high loading of nutrients from Mississippi River water through the DPD could not only increase the phytoplankton biomass in the lakes but also could result in 
species shifts to undesirable freshwater cyanobacterial dominance as what happened in Lake Pontchartrain in 1997. That is when the Bonnet Carré Spillway was opened and introduced Mississippi River water into Lake Pontchartrain in 1997 (Dortch et al. 1999; Turner et al. 2004). A bloom developed (max. $855 \mu \mathrm{g}$ Chla per liter), composed of Anabaena and Microcystis whose toxicity was sufficiently high to result in a health advisory that closed the lake to recreational contact. When the DPD was open from 2004 to 2005, there were dense blooms of Anabaena and Microcystis in both Lake Cataouatche $\left(2.97 \times 10^{8}\right.$ cells per liter) and Lake Salvador $\left(6.54 \times 10^{6}\right.$ cells per liter) in May 2005 (Ren et al. unpublished data), which was not observed previously according to the long-term monitoring data. Microcystins detected in Lake Salvador in April 2005 were at levels of $0.3-0.6 \mathrm{mg}^{-1}$ (protein phosphate inhibition assay; G. Boyer, SUNY-Syracuse, unpublished data). Although the diversion of Mississippi River water into local wetlands is hoped to be an effective coastal restoration technique (Boesch et al. 1994), the water quality of the diversions may also aggravate water quality problems in the receiving lakes adjacent to the diversion. How the ongoing changes in the upper Barataria estuary will affect the lower estuary and coastal ecosystem is unknown. Caution is needed in implementing ecosystem recovery plans, therefore, so that the unintended consequences can be identified and, perhaps, mitigated.

Acknowledgments We thank Adam Sapp, Nazan Atilla, Lora Pride, Jim Lee, Kyle Reynolds, and David Wong for assistance during the experiments and Thomas Oswald for nutrient analyses.

This work was supported by NOAA/NOS/NCCOS Center for Sponsored Coastal Ocean Research awards no. NA16OP2671 to LUMCON and no. NA16OP2670 to Louisiana State University. This is NOAA CSCOR MULTISTRESS Publication No. 101.

\section{References}

Bode, A. and Q. Dortch. 1996. Uptake and regeneration of inorganic nitrogen in coastal waters influenced by the Mississippi River: Spatial and seasonal variations. Journal of Plankton Research 18: 2251-2268. doi:10.1093/plankt/18.12.2251.

Boesch, D.F., M.N. Josselyn, A.J. Mehta, J.T. Morris, W.K. Nuttle, C. A. Simenstad, and D.J.P. Swift. 1994. Scientific assessment of coastal wetland loss, restoration and management in Louisiana. Journal of Coastal Research 20: 1-103. Special Issue.

Carlson, R.E. 1977. A trophic state index for lakes. Limnology and Oceanography 22: 361-369.

Chorus, I. and J. Bartram (eds). 1999. Toxic Cyanobacteria in Water. A Guide to Their Public Health Consequences, Monitoring and Management, 407. London: E \& FN Spon (an imprint of Routledge).

Conley, D.J., H.W. Paerl, R.W. Howarth, D.F. Boesch, S.P. Seitzinger, K.E. Havens, C. Lancelot, and G.E. Likens. 2009. Controlling eutrophication: Nitrogen and phosphorus. Science 323: 10141015. doi:10.1126/science. 1167755.

Connors, S.D., M.T. Auer, and S.W. Effler. 1996. Phosphorus pools, alkaline phosphatase activity, and phosphorus limitation in hypereutrophic Onondaga Lake. Lake and Reservoir Management 12: 47-57.

Diaz, M.M. and F.L. Pedrozo. 1996. Nutrient limitation in AndeanPatagonian Lake at latitude $40-41^{\circ} \mathrm{S}$. Archiv für Hydrobiologie 138: 123-143.

Dodds, W.K. 2003. The misuse of inorganic $\mathrm{N}$ and soluble reactive $\mathrm{P}$ to indicate nutrient status of surface waters. Journal of the North American Benthological Society 22: 171-181. doi:10.2307/ 1467990.

Dodds, W.K. 2006. Nutrients and the "dead zone": The link between nutrient ratios and dissolved oxygen in the northern Gulf of Mexico. Frontiers in Ecology and the Environment 4: 211-217. doi:10.1890/1540-9295(2006)004[0211:NATDZT]2.0.CO;2.

Dodds, W.K., A.J. López, W.B. Bowden, S. Gregory, N.B. Grimm, S. K. Hamilton, A.E. Hershey, E. Martí, W.B. McDowell, J.L. Meyer, D. Morrall, P.J. Mulholland, B.J. Peterson, J.L. Tank, H. M. Vallet, J.R. Webster, and W. Wollheim. 2002. N uptake as a function of concentration in streams. Journal of the North American Benthological Society 21: 206-220. doi:10.2307/ 1468410.

Dortch, Q. and T.E. Whitledge. 1992. Does nitrogen or silicon limit phytoplankton production in the Mississippi River plume and nearby regions? Continental Shelf Research 12: 1293-1309. doi:10.1016/0278-4343(92)90065-R.

Dortch, Q., R. Robichaux, S. Pool, D. Milsted, G. Mire, N.N. Rabalais, T.M. Soniat, G.A. Fryxell, R.E. Turner, and M.L. Parsons. 1997. Abundance and vertical flux of Pseudo-nitzschia in the northern Gulf of Mexico. Marine Ecology Progress Series 146: 249-264. doi:10.3354/meps146249.

Dortch, Q., M.L. Parson, N.N. Rabalais, and R.E. Turner. 1999. What is the threat of harmful algal blooms in Louisiana coastal waters. In Recent Research in Coastal Louisiana, 3-5 Feb. 1998, ed. L. O. Rozas, J.A. Nyman, C.E. Proffitt, N.N. Rabalais, D.J. Reed, and R.E. Turner, 134-144. Lafayette: Louisiana Sea Grant.

Dzialowski, A.R., S.H. Wang, N.C. Lim, W.W. Spotts, and D.G. Huggins. 2005. Nutrient limitation of phytoplankton growth in central plains reservoirs, USA. Journal of Plankton Research 27: 587-595. doi:10.1093/plankt/fbi034.

Elmgren, R. 2001. Understanding human impact on the Baltic ecosystem: Changing view in recent decades. Ambio 30: 222 231.

Elser, J.J., E.R. Marzolf, and C.R. Goldman. 1990. Phosphorus and nitrogen limitation of phytoplankton growth in the freshwaters of North America: A review and critique of experimental enrichments. Canadian Journal of Fisheries and Aquatic Science 47: 1468-1477.

Falkwoski, P.G. 1997. Evolution of the nitrogen cycle and its influence of the biological sequestration of $\mathrm{CO}_{2}$ in the ocean. Nature 387: 272-275. doi:10.1038/387272a0.

Fisher, T.R., J.M. Melack, J.U. Brobbelaar, and R.W. Howarth. 1995. Nutrient limitation of phytoplankton and eutrophication of inland, estuarine, and marine waters. In Phosphorus in the Global Environment, ed. H. Tiessen, 301-322. Chichester: Wiley.

Fu, F.-X., Y. Zhang, S.A. Sanudo-Wilhelmy, and D.A. Hutchins. 2005. The biological and biogeochemical consequences of phosphate scavenging on phytoplankton cell surfaces. Limnology and Oceanography 50: 1459-1472.

Fujiki, T., T. Toda, T. Kikuchi, H. Aono, and A.N.D.S. Taguchi. 2004. Phosphorus limitation of primary productivity during the springsummer blooms in Sagami Bay, Japan. Marine Ecology Progress Series 283: 29-38. doi:10.3354/meps283029.

Gobler, C.J., N.J. Buck, M.E. Sieracki, and S.A. Sañudo-Wilhelmy. 2006. Nitrogen and silicon limitation of phytoplankton communities across an urban estuary: The East River-Long Island Sound system. Estuarine Coastal and Shelf Science 68: 127-138. doi:10.1016/j.ecss.2006.02.001. 
Groeger, A.W. 2007. Nutrient limitation in Crater Lake, Oregon. Hydrobiologia 574: 205-216. doi:10.1007/s10750-006-0353-3.

Guildford, S.J. and R.E. Hecky. 2000. Total nitrogen, total phosphorus, and nutrient limitation in lakes and oceans: Is there a common relationship? Limnology and Oceanography 45: 12131223 .

Havens, K.E., E.J. Philips, M.F. Cichra, and B.L. Li. 1998. Light availability as a possible regulator of cyanobacteria species composition in a shallow subtropical lake. Freshwater Biology 39: 547-556. doi:10.1046/j.1365-2427.1998.00308.x.

Hecky, R.E. and P. Kilham. 1988. Nutrient limitation of phytoplankton in freshwater and marine environments: A review of recent evidence on the effects of enrichments. Limnology and Oceanography 33: 796-822.

Hillebrand, H., C.D. Dürselen, D. Kirschtel, U. Pollingher, and T. Zohary. 1999. Biovolume calculation for pelagic and benthic microalgae. Journal of Phycology 35: 403-424. doi:10.1046/ j.1529-8817.1999.3520403.x.

Howarth, R.W., R. Marino, and J. Lane. 1988. Nitrogen fixation in freshwater, estuarine and marine ecosystems. 1. Rates and importance. Limnology and Oceanography 33: 669-687.

Hyenstrand, P., E. Rydin, and M. Gunnerhed. 1999. Response of pelagic cyanobacteria to iron additions - enclosure experiment from Lake Erken. Journal of Plankton Research 22: 1113-1126. doi:10.1093/plankt/22.6.1113.

SAS Institute Incorporated. 2003. The SAS system for Windows, version 9.1. Cary, North Carolina, USA.

Istvanovics, V., J. Padisak, K. Pettersson, and D.C. Pierson. 1994. Growth and phosphorus uptake of summer phytoplankton in Lake Erken (Sweden). Journal of Plankton Research 16: 11671196. doi:10.1093/plankt/16.9.1167.

James, C., J. Fisher, and B. Moss. 2003. Nitrogen driven lakes: The Shropshire and Cheshire Meres? Archiv für Hydrobiologie 158: 249-266. doi:10.1127/0003-9136/2003/0158-0249.

Klug, J.L. 2006. Nutrient limitation in the Lower Housatonic River Estuary. Estuaries and Coast 29: 831-840.

Lee, D.Y. and G.Y. Rhee. 1999. Kinetics of growth and death in Anabaena flos-aquae (cyanobacteria) under light limitation and supersaturation. Journal of Phycology 35: 700-709. doi:10.1046/ j.1529-8817.1999.3540700.x.

Levine, S.N. and D.W. Schindler. 1999. Influence of nitrogen to phosphorus supply ratios and physicochemical conditions on cyanobacteria and phytoplankton species composition in the Experimental Lake Area, Canada. Canadian Journal of Fishery and Aquatic Science 56: 451-466. doi:10.1139/cjfas-56-3-451.

Levine, M.A. and S.C. Whalen. 2001. Nutrient limitation of phytoplankton production in Alaskan Arctic foothill lakes. Hydrobiologia 455: 189-201. doi:10.1023/A:1011954221491.

Lohrenz, S.E., G.L. Fahnenstiel, D.G. Redalje, G.A. Lang, M.J. Dagg, T.E. Whitledge, and Q. Dortch. 1999. Nutrient, irradiance, and mixing as factors regulating primary production in coastal waters impacted by the Mississippi River plume. Continental Shelf Research 19: 1113-1141. doi:10.1016/S0278-4343(99)00012-6.

Maberly, S.C., L. King, M.M. Dent, R.I. Jones, and C.E. Gibson. 2002. Nutrient limitation of phytoplankton and periphyton growth in upland lakes. Freshwater Biology 47: 2136-2152. doi:10.1046/j.1365-2427.2002.00962.x.

Madden, C.R., J.W. Day Jr., and J.M. Randall. 1988. Freshwater and marine coupling in estuaries of the Mississippi River deltaic plain. Limnology and Oceanography 33: 982-1004.

Maestrini, S.Y., M. Rochet, L. Legendre, and S. Demers. 1986. Nutrient limitation of the bottom-ice microalgal biomass (southeastern Hudson Bay, Canadian Arctic). Limnology and Oceanography 31: 969-982.

Mateo, P., I. Douterelo, E. Berrendero, and E. Perona. 2006. Physiological differences between two species of cyanobacteria in relation to phosphorus limitation. Journal of Phycology 42: 61-66. doi:10.1111/j.1529-8817.2006.00180.x.

Morton, T. A., J. C. Bernier, J. A. Barras, and N. F. Ferina. 2005. Rapid subsidence and historical wetland loss in the Mississippi Delta Plain: Likely causes and future implications. USGS OpenFile Report 2005-1215.

Nelson, D.M. and Q. Dortch. 1996. Silicic acid depletion and silicon limitation in the plume of the Mississippi River: Evidence from kinetic studies in spring and summer. Marine Ecology Progress Series 136: 163-178. doi:10.3354/meps136163.

Nürnberg, G.K. 1988. Prediction of phosphorus release rates from total and reductant soluble phosphorus in anoxic lake sediments. Canadian Journal of Fishery and Aquatic Science 45: 574-580. doi:10.1139/f88-054.

Paerl, H.W., L. Valdes, A.R. Joyner, M. Piehler, and M.E. Lebo. 2004. Solving problems resulting from solutions: Evolution of a dual nutrient management strategy for the eutrophying Neuse River Estuary, North Carolina. Environmental Science and Technology 38: 3068-3074. doi:10.1021/es0352350.

Parslow, J.S., P.J. Harrison, and P.A. Thompson. 1984. Saturated uptake kinetics: Transient response of the marine diatom Thalassiosira pseudonana to ammonium, nitrate, silicate or phosphate starvation. Marine Biology 83: 51-59. doi:10.1007/ BF00393085.

Parsons, T.R. 1982. The future of controlled ecosystem enclosure experiments. In Marine Mesocosms. Biological and Chemical Research in Experimental Ecosystems, ed. G.D. Grice and M.R. Reeve, 411-418. New York: Springer.

Parsons, T.R., Y. Maita, and M. Lalli. 1984. A Manual of Chemical and Biological Methods for Seawater Analysis, 173. New York: Pergamon.

Peeters, J.C.H. and L. Peperzak. 1990. Nutrient limitation in the North Sea: A bioassay approach. Netherlands Journal of Sea Research 26: 61-73.

Portielje, R. and L. Lijklema. 1994. Kinetics of luxury uptake of phosphate by algae-dominated benthic communities. Hydrobiologia 275(276): 349-358.

Postgate, J. 1998. Nitrogen Fixation, 3rd ed. Cambridge: Cambridge University Press.

Rabalais, N.N. 2002. Nitrogen in aquatic ecosystems. Ambio 31: 102 112.

Redfield, A.C. 1958. The biological control of chemical factors in the environment. American Scientist 46: 205-221.

Ren, L. 2002. Biogeochemical conversion of nitrogen in enclosed pelagic coastal ecosystems of the German Bight: Mesocosm and modeling studies. University Hamburg, http://www.sub.uni-ham burg.de/disse/775/dissertation.pdf.

Reynolds, C.S. 1993. The Ecology of Freshwater Phytoplankton, 384. Cambridge: Cambridge University Press.

Riegman, R., F. Colijn, J.F.P. Malschaert, H.T. Kloosterhuis, and G.C. Cadée. 1990. Assessment of growth rate limiting nutrients in the North Sea by the use of nutrient-uptake kinetics. Netherlands Journal of Sea Research 26: 53-60. doi:10.1016/0077-7579(90) 90055-L.

Sanudo-Wilhelmy, S.A., A. Tovar-Sanchez, F.X. Fu, D.G. Capone, E. J. Carpenter, and D.A. Hutchins. 2004. The impact of surfaceadsorbed phosphorus on phytoplankton Redfield stoichiometry. Nature 432: 897-901. doi:10.1038/nature03125.

Schindler, D.W. 1977. Evolution of phosphorus limitation in lakes. Science 195: 260-262. doi:10.1126/science.195.4275.260.

Schindler, D.W., R.E. Hecky, D.L. Findlay, M.P. Stainton, B.R. Parker, M.J. Paterson, K.G. Beaty, M. Lyng, and S.E.M. Kasians. 2008. Eutrophication of lakes cannot be controlled by reducing nitrogen input: Results of a 37-year whole-ecosystem experiment. Proceedings of the National Academy of Sciences USA 105: 11254-11258. doi:10.1073/pnas.0805108105. 
Swenson, E.M., J.E. Cable, B. Fry, D. Justić, A. Das, G. Snedden, and C. Swarzenski. 2006. Estuarine flushing times influenced by freshwater diversions. In Coastal Hydrology and Processes. Proceedings of the AIH 25th anniversary meeting \& international conference "Challenges in coastal hydrology and water quality”, ed. V.P. Singh and Y.J. Xu, 403-413. Highlands Ranch: Water Resources.

Sylvan, J.B., Q. Dortch, D.M. Nelson, A.F.M. Brown, W. Morrision, and J.W. Ammerman. 2006. Phosphorus limits phytoplankton growth on the Louisiana shelf during the period of hypoxia formation. Environmental Science and Technology 40: 75487553. doi:10.1021/es061417t.

Teaumroong, N. and S. Innok. 2002. Diversity of nitrogen-fixing cyanobacteria under various ecosystems of Thailand: 1. Morphology, physiology and genetic diversity. World Journal of Microbiology and Biotechnology 18: 673-682. doi:10.1023/ A:1016812116538.

Tilzer, M.M. 1988. Secchi disk-chlorophyll relationships in a lake with highly variable phytoplankton biomass. Hydobiologia 162 : 163-171. doi:10.1007/BF00014539.

Turner, R.E., N.N. Rabalais, and Z.N. Chang. 1990. Phytoplankton biomass, production and growth limitations on the Huanghe (Yellow River) continental shelf. Continental Shelf Research 10: 545-571. doi:10.1016/0278-4343(90)90081-V.

Turner, R.E., Q. Dortch, and N.N. Rabalais. 2004. Inorganic nitrogen transformations at high loading rates in an oligohaline estuary.
Biogeochemistry 68: 411-423. doi:10.1023/B:BIOG.0000031039. 56794.29.

Turner, R.E., N.N. Rabalais, R.B. Alexander, G. McIsaac, and R.W. Howarth. 2007. Characterization of nutrient and organic carbon and sediment loads and concentrations from the Mississippi River into the northern Gulf of Mexico. Estuaries and Coasts 30: 773-790.

Tyrrell, P. 1999. The relative influences of nitrogen and phosphorus on oceanic primary production. Nature 400: 525-531. doi:10.1038/ 22941.

Vahtera, E., M. Laamanen, and J.-M. Rintala. 2007. Use of different phosphorus sources by bloom-forming cyanobacteria Aphanizomenon flos-aquae and Nodularia spumigena. Aquatic Microbial Ecology 46: 225-237. doi:10.3354/ame046225.

Walsby, A.E., P.K. Hayes, R. Boje, and L.J. Stal. 1997. The selective advantage of buoyancy provided by gas vesicles for planktonic cyanobacteria in the Baltic Sea. The New Phytologist 136: 407417. doi:10.1046/j.1469-8137.1997.00754.x.

Wang, S., A. R. Dzialowski, W. W. Spotts, N. C. Lim, and D. G. Huggins. 2005. Variability of nutrient limitation on phytoplankton growth in small and medium Kansas lakes. Kansas Biological Survey Open-File Report No. 120.

Wilkerson, F.P., R.C. Dugdale, F.P. Chavez, and R.M. Kudela. 2000. Biomass and productivity in Monterey Bay, CA: Contribution of the larger autotrophs. Deep Sea Research II 47: 1003-1022. doi:10.1016/S0967-0645(99)00134-4. 